
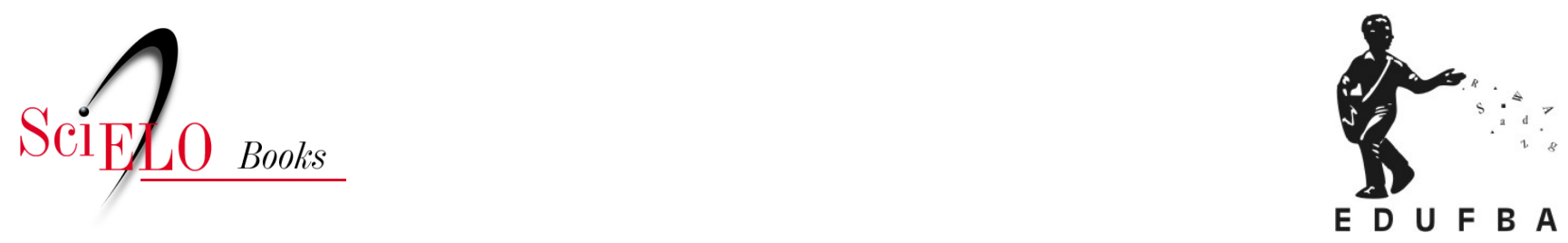

\title{
5. 0 retrato de uma comunidade pespontado nas cantigas do samba de roda
}

\author{
Nerivaldo Alves Araújo
}

\section{SciELO Books / SciELO Livros / SciELO Libros}

ARAÚJO, N.A. O retrato de uma comunidade pespontado nas cantigas do samba de roda. In: Poética oral do samba de roda das margens do Velho Chico [online]. Salvador: EDUFBA, 2016, pp. 127-186. ISBN: 978-85-232-2031-0. https://doi.org/10.7476/9788523220310.0006.

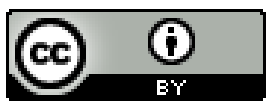

All the contents of this work, except where otherwise noted, is licensed under a Creative Commons Attribution 4.0 International license.

Todo o conteúdo deste trabalho, exceto quando houver ressalva, é publicado sob a licença Creative Commons Atribição 4.0. 



\section{0 retrato de uma comunidade pespontado nas cantigas do samba de roda}

A poética do samba de roda "É na pisada ê" retrata elementos tradicionais que compõem o amplo universo da poesia popular brasileira. Esse universo - cuja criação remonta aos tempos da colonização portuguesa com a sua tradição ibérica - abraçou particularidades da colônia do Brasil, como a influência da cultura dos colonizadores, dos povos indígenas e afrodescendentes, os quais, já se sabe, compõem a tríade principal da formação cultural brasileira.

Para se tratar da poesia brasileira, é preciso considerar que, desde a época colonial, conforme já postulava Roméro (1888), em seus Estudos sobre a poesia popular do Brazil, essa poesia tem se pautado na classe popular, porque foi ela que manteve e conservou, inconscientemente, o espírito tradicional como motivador de todo o esplendor do lirismo brasileiro, fazendo que tal poesia ocupasse um lugar de destaque. Não se trata de um velho lirismo lusitano continuado em terras brasileiras, mas de uma poesia mais exuberante que se construiu à luz da confluência dessas três forças tradicionais.

É na perspectiva de uma diversidade cultural que se vê o surgimento de uma poética popular brasileira fiel ao seu povo, às suas tradições, aos seus costumes, constituindo-se como um espaço de memória, de saberes, que permite a perpetuação de um povo e de sua cultura no decorrer dos tempos. É a poética da força, da resistência, da representação de identidades líquidas que navegam ao ritmo de águas embamburradas ${ }^{19}$ em meio a uma sociedade que se transforma, reinventa-se para seguir forte o seu rumo, sem perder a sua força e o seu retrato identitário. Logo, essa é uma poesia que sobrevive em meio às tradições de um

19 Águas turvas, reviradas, mexidas, misturadas com barro e outros elementos. Assim como as próprias culturas que se misturam e se transformam, que não existem mais em estado puro, sem "contaminação" com outras. É comum, na região ribeirinha, a expressão "embamburrar a água", no sentido de tornar a água barrenta, abarrentar, misturar com o barro, a lama e outras impurezas. A expressão "bamburrar" ou "embamburrar" vem de "bamburro", que, em Campos (2004), aparece com o sentido de sujeira, algo que atrapalha a vida e a vista. Uma espécie de matas baixas e impenetráveis. 
povo, numa espécie de movência que se traduz em um processo de consolidação da memória, o qual se implica na repetição, na criação e recriação constante.

Sobre a variação da poesia quanto às suas características formais, Menéndez Pidal (1953, p. 267, 269, tradução nossa) destaca que:

A variante não é um acidente na poesia tradicional, senão sua própria e única forma de viver: O romance vive variando de forma. Vive em variantes [...] Tanto a canção como a linguagem vivem em variação contínua e em permanência essencial. E entre o duplo balanço do indivíduo, criador de variantes, para a coletividade, que a aceita ou a deixa perder, a conduta da canção não é meramente aleatória. ${ }^{20}$

É preciso que se compreenda a poesia tradicional apontada nessas considerações como uma poesia de tradição oral, de cunho popular. Nesse âmbito, pode-se tratar da variação da poesia, tanto no aspecto estrutural, isto é, da sua forma, como versa Menéndez Pidal (1953), quanto nos aspectos temático e performático que flutuam ao sabor das intenções e posicionamentos do grupo, no que concerne à utilização da memória e das práticas tradicionais.

Pode-se considerar a poética oral ribeirinha como parte integrante do universo poético brasileiro, desde o seu surgimento, na ligação com a poética oral portuguesa, até os dias de hoje, e que vem, através da variação, da adaptação e da reinvenção, consolidando-se cada vez mais.

A poética do samba de roda ribeirinho tem a variação como uma forma de se fortalecer e de seguir navegando nas suas águas embamburradas. Pode-se afirmar isso, porque, com o passar do tempo, vem-se notando que muitas foram suas variações, principalmente no modo de se apresentar, de fazer as rodas de samba. As cantigas também estão mais organizadas, a sequência de apresentação, o cuidado com os próprios versos, com as letras, tudo segue variando ao ritmo das suas águas poéticas.

Dentro do próprio grupo, há integrantes que se preocupam com os aspectos estruturais das cantigas. Nas frequentes apresentações que ocorrem sob a forma

20 La variante no es un accidente en la poesía tradicional sino su propia y única forma de vivir: El romance vive variando de forma. Vive en variantes [...] Tanto la canción como el lenguaje viven en variedad continua y en permanencia esencial. Y entre el doble balanceo del individuo, creador de variantes, a la colectividad, que las acepta o las deja perder, la conducta de la canción no es meramente azarosa (MENÉNDEZ PIDAL 1953, p. 267, 269). 
de ensaio, há alteração dos versos, quando estes não traduzem o que gostariam de dizer ou quando estão em desarmonia com a ideia, com a estrutura da cantiga. O grupo cuida também da sequência dessas cantigas na roda, para que continue a harmonia do ritmo, das palmas e até dos temas abordados.

As cantigas vêm sofrendo ainda variações de algumas palavras em seus versos, devido ao cuidado que se vem tendo com o samba e sua poética. Mas nada tão radical que venha a descaracterizar o grupo, pois, na poesia oral, essa variação se consolida de maneira coerente.

A coerência, por sua vez, permite o reconhecimento e a integração harmônica dessa poética, sem a perda da sua identidade, promovendo a manutenção de temas e práticas, de modo que tais variações ocorram gradualmente, sem causar estranhamentos nem apagamentos de temas, modos e demais elementos da sua performance. Segundo Ferreira (1993), ao se referir a essa vivência em variantes das oralidades tradicionais nas suas diversas modalidades (cantada, contada, teatralizada ou em suas intercorrências), o texto oral, apesar de sua movência e errância, apresenta grande estabilidade. No caso da poética oral desse grupo de samba, tais variantes são consideradas como ajustes que tendem a fortalecer, a preservar, a dar mais sentido ao que se canta.

Há, portanto, uma movência ou variação das tradições populares com suas práticas, valores e ideologias que se modificam e reinventam, não apenas no âmbito estrutural ou temático das manifestações poéticas, mas nos demais elementos que compõem a cultura desse povo, tornando-a mais forte.

No samba de roda "É na pisada ê", era comum encontrar algumas cantigas com versos soltos, isto é, que não exercem, dentro da mesma composição, uma relação entre si quanto ao tema e significação. Era comum também ocorrer de modo semelhante entre palavras dispostas dentro de um mesmo verso. Isso impedia a clareza nas ideias do que se cantava. Com a mudança de posicionamento do grupo, as cantigas têm sido analisadas e revistas. Depois de pesquisas e de um cuidado maior com a composição poética entre os integrantes, algumas palavras e alguns versos estão sendo revistos e alterados, voltando a dar o sentido pretendido ao tema cantado.

Tais práticas contribuem para que a poética do samba tenha variações positivas, pois suas cantigas se tornam mais claras, mais próximas da mensagem que buscam passar. Com essa maneira de pensar e de viver o samba, surgem incorporações de novas letras e de temas por influência da realidade atual, dos 
novos ritmos e da nova geração de integrantes, porque, como já dito, no grupo, comungam gerações de bisavós, avós, pais, filhos e netos.

O próprio sentido de pertencimento dos integrantes ao grupo foi fortalecido, e o orgulho e o interesse em fazer parte desse grupo são muito mais evidentes nos dias de hoje do que antes. Então, cada vez mais, a sua poética oral vem ocupando um lugar de maior significação e de valor dentro da própria comunidade poética e em toda a região.

A poética do grupo "É na pisada ê", a cada dia, firma um espaço notório dentro da programação cultural da região, desde apresentações em escolas, nas praças durante os diversos festejos populares até em programas de televisão de alcance estadual, sendo que, antes, as rodas ocorriam, em maioria, dentro da própria comunidade em suas casas e festejos.

O samba de roda "É na pisada ê", com suas cantigas e performance, compõe o retrato da poesia popular das margens do Velho Chico, uma vez que também “vive en variantes”, conforme expressão utilizada por Menéndez Pidal (1953), para se referir à poesia popular. A poética do referido grupo vive em variações nas letras de suas cantigas, nos ritmos e ainda na maneira de se apresentar nas suas rodas de samba. Essas variações servem para estabilizar, fortalecer ainda mais o samba, para que este siga existindo como prática cultural.

Vê-se, nesse retrato pespontado, que as cantigas do samba de roda "É na pisada ê" trazem, em suas letras, muitas vezes, a representação da história e do cotidiano da comunidade de sambadores. Nessas composições, fica latente a relação com a ideologia, a religiosidade, os valores e os sentimentos do seu povo. São lamentos e lembranças de um passado que permanecem vivos nesse espaço de memória.

Pode-se inferir que a poesia do Nordeste, na qual se insere a poesia sertaneja das margens do Velho Chico, também apresenta origem ibérica, e, segundo versa Adriano da Gama Kury, na apresentação do livro Poética popular no Nordeste, de autoria de Sebastião Nunes Batista (1982), tal poesia assume uma feição peculiar, adaptando, recriando (e também criando) novas formas, novas estruturas e características que ainda permanecem tão vivas nos dias de hoje.

Constata-se que parte das características estruturais de suas cantigas como o agrupamento de versos em estrofes, a composição das rimas, o uso de estribilhos ou de repetições, também dos temas e motivações apresentam semelhanças 
consideráveis com a poesia popular medieval da península ibérica, inclusive a da atualidade.

A seguir, pode-se comprovar a ligação entre a poesia popular portuguesa e a poesia oral das margens do Velho Chico, nas duas quadras apresentadas; a primeira, da poesia popular portuguesa, pertencente à preciosa coleção do professor José Leite de Vasconcelos, um dos renomados estudiosos da poesia portuguesa, autor de obras como os seus cancioneiros; e a segunda, uma quadra que compõe o acervo das cantigas do samba de roda do grupo "É na pisada ê".

1

Não me deixa namorar

Ela também namorou

Minha mãe já não se lembra

Do tempo que já passou ${ }^{21}$

2

Oh Santo Mariano

Me dê outro marido

O marido que vós me deu

Não quer falar comigo

As duas quadras apresentam estruturas semelhantes quanto aos versos e rimas, além de também tratar de um tema relacionado ao sentimento amoroso, ao casamento e ao namoro. Parecem fazer parte da mesma comunidade poética, em uma mesma época, em um mesmo lugar ou região, no entanto, são de lugares, nações e épocas diferentes.

É uma relação que se estabeleceu através dos tempos, desde a colonização brasileira pela nação portuguesa. Nesse ínterim, temas e estruturas, os quais consubstanciavam a poesia popular desde sua origem, atravessaram "mares nunca d'antes navegados" e chegaram ao Brasil, contribuindo para a estruturação da nossa poesia popular.

O campo temático e motivador das cantigas do samba de roda ribeirinho abrange os mais diversos assuntos, os quais já compunham, há séculos, o can-

21 Quadra da coleção do professor Leite de Vasconcelos, mas que, para este estudo, foi extraída da obra O cancioneiro popular em Portugal, de Maria Arminda Zaluar Nunes. (1978, p. 103) 
cioneiro popular na península ibérica medieval e que se transpuseram ao Brasil, nesse caso, à região ribeirinha de Xique-Xique, através do colonizador português. Contudo, é preciso salientar, mais uma vez, a ampliação, em terras brasileiras, do universo de inspirações e temas proporcionados pelas culturas indígenas e afrodescendentes.

A poética oral do samba de roda é considerada como um grande retrato da vida de suas sambadeiras e sambadores, pois, em suas letras, sob a forma de poesia, cantam-se as histórias de amores, a labuta diária, os acontecimentos, as comemorações, as festas religiosas, além da moral, das ideologias e religiosidade dessa gente. Viajar nas águas dessa poética permite trazer à superfície um retrato de identidades líquidas, moventes e plurais, porque, como postula BradescoGoudemand (1982, p. 14),

\footnotetext{
A poesia popular reflete, além disso, a mentalidade peculiar do cantador, intérprete e reflexo do povo: frescura de invenção, imaginação, riqueza verbal, senso do achado pitoresco, mistura de ingenuidade e de malícia, fé, sinceridade, senso moral, e, muitas vezes, uma equilibrada dosagem de lirismo e rudeza.
}

Nesse sentido, memórias e tradições são pintadas numa espécie de tela lírica, na qual os versos atuam como imagens, cores e sons, poetecendo a história de um povo, mantendo vivas as suas práticas culturais e os seus costumes.

\section{Representações e simbologia nas cantigas do samba de roda ribeirinho}

Há uma variedade de temas e elementos representativos dentro da poesia oral do grupo de samba "É na pisada ê", os quais, como em toda cantiga popular, servem de apoio para a interpretação de usos metafóricos ou simbólicos de suas tradições, seus costumes e seus valores.

São diversas as representações trazidas pela poética desse grupo de samba. Há temas e influências que, de modo considerável, fazem parte de uma matéria geral já encontrada na poesia medieval galego-portuguesa, advinda da diversidade cultural presente no processo de povoamento da Península Ibérica, e que chegaram até a nossa poesia. 
A poética do samba de roda do grupo "É na pisada ê" versa - assim como a literatura popular portuguesa dos cancioneiros medievais, com a qual a poesia popular brasileira estabelece uma relação desde o seu surgimento - sobre temas tradicionais: cantigas amorosas, religiosas e satíricas. Acrescentam-se ainda as cantigas da natureza, do trabalho e relacionadas à vida cotidiana.

As cantigas aqui apresentadas trazem uma relação com esses aspectos temáticos, os quais contribuem para a tecedura de uma poética pelo seu próprio povo, que canta em versos a sua vida. Os motivos, as abordagens e demais elementos presentes em tais cantigas compõem uma série de características particulares que, aliadas a outros aspectos como a performance, as vestimentas e instrumentos musicais, proporcionam uma viagem pela cultura do grupo de sambadeiras e sambadores, os quais seguem seu curso, poetecendo os versos de suas poesias, enquanto, na maioria das vezes, tecem as suas redes de pesca.

Em se tratando da presença dos elementos ideológicos, da representação do cotidiano e outros aspectos relevantes, pode-se apreender que, embora sejam marcadas pela existência de traços herdados de diferentes povos e suas práticas, as quais consubstanciam toda uma pluralidade cultural brasileira, a poética oral coexiste nesse universo diverso, agindo como um meio de transmissão, de perpetuação de tradições. Isso não ocorre, no entanto, de forma alienada, impositiva ou desarticulada com o contexto social no decorrer dos tempos.

É preciso compreender, conforme Zumthor (1997), que uma cultura age sobre os indivíduos de um grupo social como uma programação contínua, fornecendo-lhe gestos, falas e ideias conforme cada situação, propondo-lhe, ao mesmo tempo, técnicas de desalienação, oferecendo as zonas de refúgio, para que se possam banir certas pulsões indesejáveis.

Ainda para o referido autor, a arte passa a ser a principal dessas técnicas, ressaltando que, de todas as manifestações artísticas, a única de cunho absolutamente universal é o canto. Entende-se que isso ocorra devido ao fato de o canto compor o universo artístico em todas as culturas. (ZUMTHOR, 1997) Desse modo, com a poética oral ribeirinha, através das cantigas de samba, pode-se visualizar um retrato da comunidade poética, seu povo e suas tradições. Sendo assim, faz-se necessário atentar para alguns elementos simbólicos, metáforas e comparações, para que se possa, através da poesia, pintar o retrato desse poeta, cantador e sambador, que se constrói e reinventa em meio a uma pluralidade de culturas e de tradições. 
Quanto à análise temática e simbólica das cantigas, torna-se imprescindível considerar que, embora se remeta, em parte, a interpretações alheias, baseadas em símbolos e representações trazidas por alguns teóricos, uma boa quantidade é composta de interpretações do autor e, como tais, não são "dogmas de fé”, como afirma Freixedo (2003), nem definitivas, pois, às vezes, é possível encontrar mais de uma interpretação coerente. Dessa forma, o leitor pode se sentir inclinado a discordar ou escolher outra interpretação que considere mais plausível, mas não esquecendo de se amparar numa fundamentação, para não cair em anacronismos nem tecer opinião subjetiva.

Segundo Nunes (1978), a poesia de caráter amoroso é considerada como um filão aurífero e incontestável dentro das produções da tradição oral popular. $O$ sentimento - especialmente o amoroso - e os estados da alma permeiam boa parte da poesia popular, inclusive nas margens do Velho Chico. Nota-se, então, que boa parte das composições desse grupo de samba traz essa característica lírico-sentimental.

São queixas, lamúrias e confissões que revelam a dor da saudade, do abandono, do descaso e emoções. São relatos de amores não consumados por diversos motivos e de desejos que habitam o eu lírico, cujo sofrimento é revelado através dessas confissões. Ressalta-se que o eu lírico pode aparecer nas cantigas do samba de roda representado tanto pela mulher quanto pelo homem, embora o sentimento feminino venha a se sobressair em sua grande parte.

Quando traz o sentimento feminino, a poética oral ribeirinha se aproxima em seus temas da canção peninsular de mulher, sobre a qual versa Menéndez Pidal (1953), quando se refere à temática essencial da canção de mulher na Península Ibérica: a dor da ausência, o temor quando o amado não comparece ao encontro marcado, a enfermidade do amor, o júbilo de sua chegada, o pudor e a recusa às carícias, às tentações carnais.

A canção de mulher permeia todo o universo da poesia oral desde os tempos mais antigos, como ressalta Asensio (1970, p. 24, tradução nossa),

A canção de mulher enamorada floresce sob todos os céus e se canta em todas as línguas desde tempos remotos [...] Tal é a unanimidade de certos temas, como a dor de amor ou a nostalgia do ausente e até 
mesmo algumas imagens que retratam a paixão. Por todas as partes

os momentos dolorosos são mais insistentes que os gozosos [... $]^{22}$

Como se nota, embora já sejam temas presentes na poesia medieval ibérica, estes também são encontrados na trama dos fios poéticos da lírica ribeirinha que, do mesmo modo, traz, em versos, o sentimentalismo amoroso, inclusive nos dias de hoje, como é o caso das cantigas de samba do grupo "É na pisada ê".

$\mathrm{Na}$ cantiga a seguir, o eu lírico - nesse caso, feminino - confessa a sua dor, seu arrependimento pela ingratidão do ser amado. O elemento ao qual faz a confissão é uma viola, instrumento que costuma acompanhar as cantigas. Nesse caso, a viola chora, simbolizando o seu choro, a sua dor pela desilusão amorosa, o que é recorrente nas letras de outras composições do grupo, a exemplo da lamentação da cantiga a seguir:

Chora, viola, chora

Chora, viola da mina

Vai dizer àquele ingrato

Que eu ainda estou na mesma sina

Se eu soubesse quem tu era

Ou quem tu haverá de ser

Não dava o meu coração

Para hoje eu padecer

Chora, viola, chora,

Chora, viola da mina

Como se vê, aqui, a mulher confessa à viola a sua dor e decepção pelo amado. Após ter lhe dado o seu amor, o seu coração e, possivelmente, ter cedido aos seus desejos, entregando-lhe a sua virgindade, há o padecimento feminino provocado, certamente, pelo abandono, pela traição por parte do seu amado. Os versos "Se eu soubesse quem tu era/Ou quem tu haverá de ser" comprovam o desapontamento e o desengano com o ser amado.

22 La canción de mujer enamorada florece bajo todos los cielos y se canta em todas las lenguas desde tempos remotos [...] Tal es la unanimidad de ciertos temas, como el insomnio de amor o la nostalgia del ausente y aún de ciertas imágenes em que trasluce la passión. Por todas las partes los momentos dolorosos son más insistentes que los gozosos [...]. (ASENSIO 1970, p. 24) 
O amado, como muitos outros homens, aparece bem menos tocado pelo sentimento do amor, e seu objetivo maior, em muitos casos, é a busca do prazer, da consumação do ato sexual. As juras de amor eterno terminam junto com o jogo da conquista, quando a mulher cede e se entrega.

Há ainda uma alusão ao cotidiano, ao lugar onde vive, quando se refere à "viola da mina", pois, na região, era comum haver minas de ouro e de pedras preciosas, visto que, nas proximidades, encontra-se a Serra do Assuruá, local em que se localiza, atualmente, o município de Gentio do Ouro, com a atividade de garimpo sendo desenvolvida até hoje em minas, riachos, grutas etc. Assim, a cantiga também retrata uma circunstância em que se supõe ouvir o som de alguma viola ao longe, numa mina, fazendo aflorar o sentimento, a melancolia do eu lírico.

A virgindade e a pureza feminina aparecem sempre como uma prenda, da qual o amado vive constantemente em busca, e a mulher, tentando resistir. E quando cede às tentações carnais reprimidas pelos princípios religiosos, pensando que passará a gozar de plena felicidade ao lado do amado, na maioria das vezes, acaba sendo abandonada por ele, que sai em busca de outra donzela. É o caso da cantiga seguinte:

A laranja madura caiu

Caiu na água e foi ao fundo

Triste da moça donzela

Que caiu na boca do mundo

Nesses versos, nota-se que, após sofrer o abandono pelo amado, a moça ainda é exposta aos olhos da sociedade, sofrendo rejeições familiares e privações, fato ainda muito comum nas comunidades de princípios e valores conservadores, nas quais as influências religiosas são até hoje muito marcantes. Nesse sentido, Freixedo (2012, p. 50, tradução nossa) versa que "como se pode comprovar, na poesia popular, estabelece-se uma relação de causa e efeito entre a perda da virgindade e o fato de que a moça fique solteira”. ${ }^{23}$ Circunstância semelhante ocorre nas cantigas do samba ribeirinho.

23 "como se pode comprobar, na poesia popular estabelécese unha relación de causa efecto entre a perda da virxindade e o feito de que a moza fique solteira". (FREIXEDO 2012, p. 50) 
Atualmente, em alguns casos, parece haver uma tolerância maior, embora, mesmo nos dias de hoje, moças que tenham sido conquistadas e abandonadas ainda acabem sendo mal vistas em seu meio, tidas como perdidas e motivo de falação de toda a comunidade quanto à sua reputação. A moça "perdida", nesse caso, só vem a ter o seu nome "limpo", quando consegue se casar com um rapaz "de boa família”, passando, com isso, a ser reintegrada ao meio social.

Na cantiga, a metáfora da virgindade se dá quando esta é comparada a uma laranja madura, desejada, a qual todos querem tê-la, chupá-la. O verso "Caiu na água e foi ao fundo" representa o momento em que a moça se entrega, perdendose em meio ao ato sexual, caindo na boca do mundo. Há vários casos, na poesia popular, em que a virgindade surge representada como uma fruta apetitosa, um prato saboroso ou uma joia de valor, sendo também, dessa maneira, nas cantigas do samba de roda ribeirinho.

Dentro desse âmbito temático, há ainda a composição na qual a mulher faz um apelo ao Santo Mariano, pedindo-lhe outro marido, uma vez que o seu não lhe dirige a palavra, provavelmente por causa de algum desentendimento ou desamor. E por isso ela sofre, clama ao seu santo de devoção por outro amor que lhe dê atenção. É comum perceber, em algumas cantigas, a presença da religiosidade, quando se tem um santo, a Virgem Maria ou Nossa Senhora como uma espécie de interlocutor, conforme se nota nos versos a seguir:
Oh Santo Mariano
Me dê outro marido
O marido que vós me deu
Não quer falar comigo

Na sequência, apresenta-se uma cantiga em que se percebe, com mais ênfase, essa abordagem comum nas composições poéticas do grupo: o jogo de sedução entre os amantes, a busca pela consumação do desejo amoroso. Essas cantigas retratam, através das práticas do cotidiano, o universo da conquista, da corte entre os amantes, tão comum na poesia popular, como se observa nas seguintes quadras:

Curimatá tá lavando

Lá na beira do rio. 
Ô que peixe danado

Curimatá, é dourado.

Ela lava de um lado

Ele lava do outro

Ô que peixe danado

Curimatá, é dourado

Nessas quadras, faz-se referência ao ato de lavar, atividade comum quando se tem como espaço o rio. Na poesia popular, a fonte e o rio quase sempre aparecem como lugares nos quais os amantes se encontram às escondidas, pois era um hábito para a mulher ir à fonte, buscar água, banhar-se ou mesmo lavar roupas, louças etc. Assim, essa atividade da labuta diária vem motivando várias composições da poesia oral no decorrer dos tempos. Nas margens do Velho Chico, a poesia também traz, em suas composições, tal referência, pois é no rio que se pesca, toma-se banho, tratam-se os peixes, lavam-se as roupas, as louças etc. Muito comumente, o rio passa a ser visto como o lugar de asseio, limpeza, encontros, sedução e fertilidade.

O hábito de se lavar, de tomar banho nas águas do rio acaba despertando o jogo erótico da nudez, da revelação de partes mais reservadas do corpo ou mesmo deste por inteiro. É o momento em que, muitas vezes, ocorrem os encontros amorosos, as entregas entre os corpos dos amantes, burlando-se as regras, os princípios de uma sociedade, a qual, até os dias atuais, valoriza (ainda que de maneira hipócrita) o discurso de que é preciso ser fiel à castidade, à virgindade e ao pudor diante da nudez.

Segundo Freixedo (2012), na poesia popular, há um valor simbólico do ato de lavar o corpo, os cabelos, as roupas, algo de valor erótico e sensual. Assim, os versos da cantiga apresentada anteriormente demonstram essa relação e o seu valor simbólico quando traz: "Ela lava de um lado/Ele lava do outro”. Há um jogo erótico da sedução de ambos os amantes quando se subentende que há uma insinuação, um convite à consumação de um desejo íntimo.

Ir à fonte ou ao rio buscar água, lavar roupas, pescar, banhar-se significa um momento de perigo, de tentação para a mulher em especial, pois o encontro com o amante pode significar a perda da inocência, da pureza da mulher apaixonada, 
sempre tão bem advertida pela mãe, pela família, para que tenha cuidado com os homens e suas estratégias de sedução.

O homem, nesse caso, aparece representado por um peixe, o dourado. Isso fica claro quando se canta nos versos: "Ô que peixe danado/Curimatá, é dourado”. Já com a mulher, faz-se comparação ao peixe curimatá, que possui nome feminino. Demonstra-se, na cantiga, o jogo sedutor do dourado para com a curimatá. Mais uma vez, nota-se a presença de elementos e situações do cotidiano que permeiam as cantigas, sendo o peixe tão presente no universo ribeirinho.

Na próxima cantiga que se segue, o sentimento amoroso encontra-se presente, fica latente o desejo do eu lírico de estar junto, de ter a companhia do ser amado. Apesar de não estar definido, com evidências, o gênero do eu lírico, subtende-se, a partir das lamentações pela dor da ausência e desejo do encontro, ser feminino. A dificuldade para a consumação do desejo pelo encontro entre os amantes é comum e, então, há o apelo ao santo de devoção para que este intervenha.

Ô piaba ê, piaba ê

Valei-me Nossa senhora

Ô Piaba ê, piaba ê

Santana do Miradouro

Ô Piaba ê, piaba ê

Me bote daquele lado,

Ô Piaba ê, piaba ê

Nos braços do meu amor

Ô Piaba ê, piaba ê

Observa-se, mais uma vez, a presença de elementos da cultura local e da lida diária com a pescaria, como o peixe, o rio, suas águas, além da fé em Nossa Senhora Santana da Ilha do Miradouro. Na cantiga, a piaba, peixe comum da região, repetidamente, aparece no refrão, demonstrando como os peixes e outras referências locais são vastamente utilizados na composição do universo dessa poética. Surge também a referência à Nossa Senhora, como uma marca de fé e religiosidade.

Assim como em várias outras composições poéticas, o sentimentalismo amoroso se exalta em meio às representações cotidianas, uma vez que é desta- 
cada a vontade do eu lírico de estar na outra margem, ao lado da pessoa amada, fazendo irromper o desejo amoroso entre os amantes, a saudade, a angústia pela distância.

Os encontros às escondidas, os quais são mais comuns nas fontes, em espaços próximos ao rio e até em seu leito, dentro de suas águas, é um momento em que muitas moças consideradas donzelas podem ter a oportunidade de se despir dos pudores, das amarras impostas pelos dogmas sociais instituídos pela Igreja. É quando podem deixar fluir, em seu corpo, o desejo sexual. O apelo erótico, então, realiza-se com o jogo da sedução. Sabe-se que a nudez, o banho, a água sobre o corpo e determinados gestos fazem parte de um erotismo, o qual, através das cantigas, pode ser percebido, imaginado, visualizado e até sentido.

Em cantigas como essas, pode-se apreender que muitas moças de conduta íntegra, exemplar, que nem sequer bailam ou cantam para não colocar em xeque a sua pureza, aproveitam esses momentos para burlar as doutrinas religiosas cristãs, quase sempre, castradoras do prazer, sobretudo, feminino. Isto é, dirigem-se às fontes com a justificativa de realizar as atividades rotineiras e, lá, entregam-se, caindo em tentação.

As moças mais bem educadas, religiosas e de famílias mais abastadas, tradicionais, muitas vezes, cedem, pois "talvez as hipócritas que não cantam nem bailam por seguirem os mandados da moral cristã de não exibir a sensualidade, são as que caem primeiro em tentação”. (FREIXEDO, 2012, p. 50, tradução nossa $)^{24}$

O rio e as suas águas estão presentes em praticamente todos os momentos da vida das nossas sambadeiras e sambadores e, assim também, dá-se no seu universo poético. Na maioria das suas cantigas, os diversos elementos e situações relacionadas às águas sempre aparecem, tais como: lagoa, rio, pesca, peixes, embarcações, banhos, personagens mitológicos das águas (Mãe d’Água, Nego d’Água, Serpente do Miradouro) etc.

Desse modo, pode-se considerar que, dentro do universo da poética ribeirinha, "a água é o símbolo das energias inconscientes, das virtudes informes da alma, das motivações secretas e desconhecidas”. (CHEVALIER; GHEERBRANT, 2009, p. 21-22) Isso porque passa a estar associada a momentos de busca pela

24 "talvez as hipócritas que non cantan nin bailan por seguir os mandados da moral cristiá de non exhibir a sensualidade, son as que caen antes na tentación". (FREIXEDO, 2012, p. 50) 
realização de sonhos, de desejos, de anseios secretos e desconhecidos, os quais habitam no íntimo de cada indivíduo, sendo que, muitas vezes, libertam-se dessa prisão e são concretizados em meio a medos e curiosidades, desejos e culpas. E esses momentos de libertação acontecem, na maior parte das vezes, dentro da água ou em suas proximidades.

A água permite aguçar, transcender, ir além do conhecido, entregar-se, pois, quando se faz presente em meio ao encontro amoroso, ao sexo, ao prazer, tornase símbolo de fecundidade, de vida, e também, de regeneração, já que o banho, após o encontro amoroso, pode limpar, regenerar, esconder. Assim, na lírica do samba de roda ribeirinho, em conformidade com Chevalier e Gheerbrant (2009), pode-se afirmar que a água apresenta significações simbólicas em três temas dominantes: fonte de vida, meio de purificação e centro de regenerescência.

Dessa forma, a moça donzela, que "como a laranja madura, caiu na água e foi ao fundo", pode se regenerar, purificar-se para não "cair na boca do mundo", através do banho, no momento em que se lava, limpa-se, como se estivesse livrando-se, com isso, do pecado da luxúria. Logo, a água cumpre o papel de uma espécie de purificação e regenerescência, pois vem esconder ou mesmo dar fim aos resquícios do pecado diante da sociedade, mantendo-a pura e casta perante os olhos da sociedade e da Igreja.

Na próxima cantiga, a lagoa surge como local do encontro, um lugar propício à realização dos desejos, lugar de água com toda a sua representação. Vale ressaltar que o lago - no caso da cantiga, uma lagoa -, segundo Chevalier e Gheerbrant (2009), traz uma significação de paraísos ilusórios, simbolizando as criações de uma imaginação exaltada. Na próxima cantiga, a lagoa passa a ser um paraíso para os amantes, uma vez que se constitui no cenário de um encontro. Esse paraíso, no entanto, pode ser ilusório, pois o encontro pode vir a ser descoberto ou gerar arrependimento, desilusão por parte de um dos amantes, especialmente, da mulher, a qual pode vir a ser abandonada, exposta e discriminada na sociedade. O lago ou lagoa, conforme aparece na próxima quadra, vem representar um lugar de risco, uma armadilha. É preciso ter cuidado na beira da lagoa, pois pode ser perigoso cair dentro dela, isto é, cair numa cilada, por dar asas às imaginações e aos desejos exaltados, proibidos.

Ainda na cantiga a seguir, o convite ao encontro amoroso não acontece de forma direta, mas através de expressões de sentido figurado. Subtende-se que o convite não é para a realização da tarefa cotidiana, tirar marimba, mas utilizar 
tal motivo para que os amantes possam se encontrar em um lugar longe das vistas das pessoas, a fim de aproveitar o momento a sós para namorar, livremente, longe das proibições sociais, como se observa:

Vamos tirar marimba, meu bem

Na beira da lagoa

De dia não tenho tempo, meu bem

De noite não tem canoa

Nos versos anteriormente citados, os amantes procuram um encontro e utilizam uma desculpa para que este se concretize. Contudo, há empecilhos apontados: a falta de tempo durante o dia; e a falta de canoa à noite. Supõe-se, a partir dos dois últimos versos, que há um jogo por parte de um dos amantes, certamente, uma mulher. Deduz-se se tratar de uma figura feminina, a partir da observação de outras cantigas, as quais retratam, na maioria das vezes, o universo feminino. A mulher apresenta motivos para não ir ao encontro e correr o risco de ficar mal vista, de se entregar aos seus desejos carnais e "cair na boca do mundo", como mostrou outra cantiga já apresentada.

Um dos amantes faz o convite ao outro para tirar marimba na beira da lagoa, embora o seu objetivo maior não seja realizar propriamente a atividade da colheita da marimba, mas um meio de encontrar o outro. Segundo os dicionários e as próprias sambadeiras, marimba é uma tipo de fruta seca da abóbora marimba ou abóbora d’água, que forma uma espécie de cabaça oca, a qual, trabalhada artesanalmente com uma abertura no fruto, torna-se um prático recipiente para ser utilizado, inclusive, no armazenamento e transporte de água.

Tirar marimba deveria significar, então, ir até à beira da lagoa para colher tal fruto, muito encontrado nas margens das lagoas e rios na região, porém, nesse caso, a atividade é usada como uma desculpa para o encontro amoroso. E mais uma vez, o encontro acontece próximo às águas, nesse caso, uma lagoa. Há também outras correspondências associadas à palavra "marimba", como instrumento musical e, ainda, uma espécie de peixe do atlântico, embora, nesse caso, com uma alteração para "marimbá”. Também aparece, em alguns lugares, como sinônimo de pênis. Porém, o que mais se aproxima da realidade ribeirinha é a relação com a fruta da abóbora marimba, inclusive, pelo relato das próprias sambadeiras e sambadores. 
Numa análise mais ousada, é possível comparar a expressão "tirar marimba" ao namoro, ao próprio ato sexual, especificamente, à conquista da virgindade e da pureza da mulher, uma busca frequente dos homens. A própria forma de perfurar a cabaça oca pode vir a ser comparada à pratica do sexo, à ruptura do hímen, à perda da virgindade. E a mulher, já supondo isso, justifica não ter tempo durante o dia e não haver canoa à noite. Em cantigas como essas, manifesta-se um contínuo jogo de sedução, de busca do prazer, do proibido, no qual, muitas vezes, a mulher aparece envolvida em pudores, tentando recusar às carícias e às tentações carnais, um dos temas da poesia oral trazidos por Menéndez Pidal (1953), já apontados anteriormente nesta discussão.

A seguir, em mais uma cantiga apresentada pelo grupo, predomina a temática do namoro, do sentimento amoroso:

Vou-me embora mais o vento

Vou fazer casa no ar

Vou fazer porta de vidro

E janela pra namorar

O desejo de construir janelas para namorar aparece retratado nos versos, uma vez que se tem conhecimento do namoro na janela, na qual a donzela permanecia, no intuito de ver o seu amante passar, de lhe lançar um olhar e, quando possível, atirar-lhe um beijo. Nesse caso, é pela janela que se dá a comunicação entre os amantes, pois a donzela, muitas vezes recolhida em seus aposentos, em seu lar, em meio às atividades domésticas, podia escapar um pouco da repressão da família para ver seu amado. E esse amado também tinha a janela como um símbolo de união, um elo, em momentos nos quais o encontro físico não podia se concretizar.

Em circunstâncias mais subversivas, a janela era a porta de fuga da donzela para ir ao encontro do seu amado, especialmente, à noite ou quando não havia uma vigilância maior pela família ou vizinhança. Através da janela, era possível receber o seu amado em seus aposentos, considerados pelos seus tutores como um lugar de segurança para uma donzela. E a janela acaba rompendo com esse paradigma, transformando-o em um lugar perfeito para a consumação do amor. Segundo Chevalier e Gheerbrant (2009), a janela passa a simbolizar a receptividade ao que vem aos olhos. Nesse caso da cantiga, uma receptividade ao amado 
e seus artifícios de sedução. Esse tão recorrente cenário de amor nordestino, em que a janela é elemento central no espaço da trama, também surge no cancioneiro contemporâneo brasileiro, a exemplo da letra do forró "Esperando na janela" (2004), ${ }^{25}$ de autoria do compositor, cantor e sanfoneiro pernambucano Targino Gondim, ${ }^{26}$ em parceria com Manuca Almeida e Raimundinho do Acordeom: "Por isso, eu vou à casa dela/ Falar do meu amor pra ela/ Tá me esperando na janela/ Não sei se vou me segurar...”.

Além da janela, a porta de vidro traz uma significação de liberdade, tanto pela sua transparência, que permite ver o outro lado, contemplar o amado, como também pela fragilidade do vidro, que poderia ser quebrado, permitindo a fuga e o encontro dos amantes. A porta, conforme Chevalier e Gheerbrant (2009) simboliza um local de passagem - em especial, nesses versos - entre duas realidades: a da prisão e do desejo; e a da fuga e do prazer.

Nota-se, ainda na mesma cantiga, a presença do vento como companheiro, que pode levá-la embora para lugares distantes, desconhecidos. O vento surge como sinônimo de liberdade e, "devido à agitação que o caracteriza, é um símbolo de vaidade, de instabilidade e inconstância”. (CHEVALIER; GHEERBRANT, 2009, p. 935) Tal simbologia se aplica a essa cantiga, a qual retrata toda a incerteza, a instabilidade e a inconstância em que vivem os amantes.

Em relação ao vento como elemento simbólico trazido nas cantigas, segundo Freixedo (2012), o próprio Miguel Torga sugere, em relato incluído na obra Novos contos da Montanha, que o vento também aparece simbolizando este elemento masculino: o homem, o namorado, que, no caso das cantigas de samba, chega para desestabilizar a mulher, com sua insistência, suas investidas para tê -la, para conquistar o seu amor e seus carinhos.

Dessa forma, a mulher vê-se envolvida em sentimentos incertos, tornandose instável e insegura, pois precisa conviver entre a razão (submetida às regras de comportamento social) e a emoção, que lhe atira aos braços do amado sedutor, o qual a desperta para sentimentos e atitudes proibidas por uma educação repressora e punitiva quanto ao corpo, ao sexo, ao prazer.

\footnotetext{
25 Letra e vídeo disponível em: <https://www.youtube.com/watch?v=ROBe2-durTo>. Acesso em: 15 ago. 2014 .

26 Biografia e discografia no Dicionário Cravo Albin da música popular brasileira. Disponível em: <http:// www.dicionariompb.com.br/targino-gondim/dados-artisticos>. Acesso em: 15 ago. 2014.
} 
No verso "Vou-me embora mais o vento", este (o vento) pode ser visto por essa ótica como símbolo do amante, do namorado, o qual possibilitará à moça novas aventuras, a realização de sonhos, a fuga de uma realidade de privações e tolhimentos, mesmo que a nova realidade pareça incerta, como "a casa no ar".

Esse vento pode desviar a moça do bom comportamento esperado para uma donzela, de assanhá-la, desestabilizá-la, fazê-la cair em tentação e até levá-la consigo para outros mundos diferentes, contrários do que é esperado. E a casa no ar, por sua vez, passa a representar toda a incerteza, a instabilidade que a espera, de uma vida fora da normalidade cotidiana arraigada nos valores familiares e cristãos.

Segundo Freixedo (2012), na poesia popular, a ideologia moral da sociedade patriarcal e cristã traz a necessidade de se precaver contra o vento, que pode ser traiçoeiro, invasivo, revelar partes do corpo feminino sorrateiramente. Enfim, em várias situações, o vento é simbolizado pela turbulência, inconstância, pelo perigo. Por isso, chega a ser associado ao elemento masculino, ao homem e às suas artimanhas no jogo da sedução para com a mulher.

A ideologia moral de uma sociedade patriarcal e cristã, que determina certas normas de conduta à mulher como a virgindade, aparece na cantiga subsequente:

No Rio São Francisco

Tem duas coisinhas belas

Cabeça de curimatá

Beijinho de moça donzela

Nesses versos, também, percebe-se a forte ligação com o rio, as águas, os peixes, elementos que fazem parte da cultura ribeirinha. Das "duas coisinhas belas encontradas no rio”, uma é a cabeça de curimatá, peixe comum na região, a que se atribui tal beleza pela sua fartura, pelo sucesso da pescaria, pois nada melhor para o pescador do que ver, na rede ou no anzol, a cabeça do peixe que foi fisgado.

A outra "coisinha bela" é o "beijinho de moça donzela”. Esse beijo de moça donzela vem representar a conquista da amada durante o jogo de sedução. É a prenda desejada, a pescaria mais buscada nesse universo de encontros, de busca do prazer, pois o homem dessa poética ribeirinha, um exímio e persistente pes- 
cador, sempre se encontra tentando fisgar a mulher, que, muitas vezes, deixa-se seduzir pela isca lançada e se prende ao anzol.

Prender-se ao anzol, deixar-se fisgar representa, para essa moça, a entrega de sua "donzelice", um dos maiores perigos para ela, pois pode significar a sua perdição, trazendo-lhe, após o prazer, muitas dores futuras, caso venha a "cair na boca do mundo", ser mal falada.

A expressão “donzela” é trazida como um símbolo de preciosidade, de valor. É apresentada a figura da mulher pura, virgem, como o ideal de mulher, uma marca da cultura eurocêntrica, patriarcal e cristã, que ainda se faz presente no discurso ribeirinho. Por isso, o beijinho de moça donzela é considerado como belo e precioso, uma vez que a virgindade é uma das qualidades exigidas para a moça na noite de núpcias, momento em que ela a oferta ao seu marido, após as bênçãos e consentimentos da Igreja.

O sentimento amoroso, o desejo da conquista e o jogo da sedução podem ser vistos também na composição que se apresenta a seguir:

Dançadeira que quer

Dançar tão miudinho

Se não dança ao meu gosto

Dance mais um bocadinho

Os versos expressam a admiração de um cavalheiro pela moça com sua dança, seu samba, sendo que ele aproveita o momento, no qual a amada se exibe, para cortejá-la. Nas comunidades de tradição popular, sempre foi muito comum a realização de encontros festivos e religiosos, os quais se tornaram momentos propícios para que muitos casais pudessem se ver.

Em momentos como esses - as festas de colheita e de padroeiro, as quermesses e outros tipos de comemorações religiosas -, muitos casais se conheciam e se apaixonavam. Como, na maioria dos casos, a moça não podia sair sozinha para outros encontros, era nessas festas que surgia a oportunidade de namorar, pois os amantes sempre davam jeito de escapar um pouco da vigilância social e se encontravam às escondidas.

Nesse sentido, convém destacar as palavras de Freixedo (2012, p. 51, tradução nossa): "E tanto no século XX como na idade média, para a juventude rural 
a celebração religiosa era sobretudo um pretexto para os encontros amorosos". ${ }^{27}$ Nos dias de hoje, nas margens do Velho Chico, essa prática ainda permanece, quando as rodas de samba, que ocorrem nas festas de santos e padroeiros e em outras oportunidades, vêm representar uma possibilidade de encontro entre os amantes ou mesmo para que se possam conhecer pessoas e começar um namoro.

As rodas de samba também servem como pretexto, como situação propícia ao namoro e ao jogo da sedução. A dançadeira, ao “dançar tão miudinho”, mostra-se, insinua-se ao rapaz, exercendo a sua sensualidade através dos passos do samba. Desse modo, pode seduzir seu pretendente, deixá-lo encantado, esperando que "dance ao seu gosto e mais um bocadinho". "Dançar ao seu gosto" passa a significar o namoro em si, com as suas carícias e outras trocas de intimidades. Mas como ela não podia, naquele momento, “dançar ao seu gosto”, realizando seus desejos, restava ao rapaz admirá-la na sua forma de dançar.

Ainda na perspectiva temática do sentimento amoroso e do jogo de sedução, o homem sempre aparece buscando a realização dos seus desejos íntimos, a conquista do prazer nos encontros às escondidas, e a mulher, na maioria das vezes, esquiva-se, por pudores e medo de ser descoberta e ficar mal vista no seu meio. Também sobre esse medo, apresenta-se mais uma cantiga:

Menina, você quer, eu quero

Não se ponha a imaginar

Quem imagina, toma medo

Quem tem medo, não vai lá

Nesses versos, nota-se um eu lírico masculino afirmando querer o mesmo que a menina também deseja, mas esta, ao contrário dele, imagina as consequências do seu desejo e tem medo de concretizá-lo. O rapaz a motiva para o encontro e, possivelmente, para que, "indo lá", ela possa entregar-se a ele, ao prazer. Ele pede à moça ("menina”) que "não se ponha a imaginar”, pois "quem imagina, toma medo" e acaba desistindo. Então, para ele, não se pode pensar muito, deve-se agir de imediato, sem analisar as consequências, pois há toda uma confluência de valores sociais para que a menina não venha a se subverter perante os preceitos cristãos.

27 "E tanto no século XX coma na idade media, para a xuventude rural a celebración relixiosa era sobre todo un pretexto para os encontros amorosos". (FREIXEDO, 2012, p. 51) 
Outra cantiga também remete a esse jogo da conquista, da sedução do galanteador, que busca conseguir o seu amor, o seu carinho. Nela, o rapaz a convida para um jogo, no qual lhe dá duas alternativas. Ambas lhe proporcionam a conquista:

Menina, vamos jogar

O jogo da laranjinha

Se eu perder, você me ganha

Se eu ganhar, você é minha

Nos versos “Se eu perder, você me ganha/Se eu ganhar, você é minha”, o jogo dos contrastes passa a ser utilizado como uma estratégia de ganho para o sedutor.

A seguir, mais uma cantiga traz representada, também, em meio a afazeres cotidianos, o desejo da conquista, a sedução amorosa, a paixão entre os amantes:

É machado no pau

É cavaco voando

Ai, menina, me chama

Eu não tou esperando

Uma ferida magoada, ai ai

E danada pra ver, ai ai

É machado no pau

É cavaco voando

Ai, menina, me chama

Eu não tou esperando

Uma ferida magoada, ai ai

Doi, dói, ó malvada, ai, ai

Nos versos anteriores, um dos afazeres cotidianos, como o hábito de cortar a lenha, é descrito claramente: “É machado no pau/É cavaco voando”. Sendo que, em meio aos seus afazeres, o eu lírico dirige-se à amada, lamentando a sua mágoa, a dor que sente por causa de uma ferida magoada. Nessa relação, uma ferida aparece causada, talvez, pela recusa do amor que o eu lírico dirige à amada, ou pelo abandono, desprezo ou impossibilidade de encontrar a amada e de provar 
do seu amor. E por essa instabilidade sentimental, o amante sofre em meio à sua labuta.

Como se comprova, o viés temático das cantigas apresentadas até agora gira, na maioria das vezes, em torno do sentimentalismo amoroso. Não são muitas as cantigas em que, mesmo tendo outros temas tratados em seus versos, deixa-se de demonstrar um caráter amoroso e sentimental, um estado d'alma.

A cantiga seguinte faz que se perceba uma conotação erótica, quando, nela, aparece o elemento "lapa”, como lugar de prazer, lugar de vadiar, brincar.

No caminha da lapa

Tem uma pedra mal lavada

Quando eu passo tá enxuta

Quando eu volto tá molhada

Eu vou vadiar na lapa

Eu vou vadiar na lapa

De acordo com o Michaelis Moderno Dicionário da Língua Portuguesa (WEISZFLOG, 2009), o vocábulo "lapa” é uma cavidade em rochedo, uma espécie de cova, de gruta. O veio erótico da cantiga se consolida através de uma possível comparação da lapa ao órgão sexual feminino. Uma cavidade que se subtende ser o órgão sexual feminino, pela qual, quando se passa, encontra-se enxuta e, quando se volta, molhada. Evidencia-se aí mais uma vez, a utilização do jogo dos contrastes em uma cantiga. Nesse caso, o contraste "enxuta/molhada" remete a uma representação de uma circunstância que integra a própria relação sexual entre os amantes, que se excitam e se molham de desejo, sendo que o próprio gozo masculino também deixa o órgão sexual feminino molhado.

O eu poético praticamente descreve, por meio de metáforas e símbolos, o ato sexual, inclusive, considerando-o como um momento de prazer, no qual a lapa representa o local que lhe permite vadiar, brincar: "Eu vou vadiar na lapa". Vê-se retratado, nessa vadiagem, portanto, o movimento do órgão sexual do homem entrando e saindo, deixando, com o seu gozo, o órgão sexual feminino umedecido e molhado, o qual é representado pela lapa, uma espécie de gruta. A presença de motivos eróticos, como se pode notar nessa cantiga de samba, já era comum ocorrer na lírica popular há muitos séculos. Freixedo (2012, 
p. 63, tradução nossa), quando versa a respeito de alguns motivos eróticos medievais na poesia galega de tradição oral, conclui:

Constata-se que, em efeito, na lírica popular contemporânea registram-se numerosos motivos ou elementos (especificamente de significado erótico), tratados na maioria das vezes, com procedimentos metafóricos e/ou simbólicos pode-se dizer que similares aos empregados, sete ou oito séculos antes, nas cantigas de amigo de tipo tradicional. É muito provável que, apesar das diferenças abismais de todo tipo entre ambos registros, a origem destes motivos e procedimentos seja a mesma: uma tradição oral antiga, pré-trovadoresca. ${ }^{28}$

Ainda, segundo o autor, muitos eram os elementos da natureza utilizados com conotação erótica, tais como a fonte, a cântara, a flor, a horta, dentre outros. Seguindo esse viés analítico das cantigas, outra abordagem marcante dentro da poética oral ribeirinha a se considerar é a existência dos elementos da natureza cotidiana como os animais, as árvores, flores e as frutas etc., com as possíveis relações simbólicas estabelecidas em seus versos. Na poesia popular, é comum encontrar a presença de animais em suas composições, muitos sendo trazidos dentro de um campo simbólico e comparativo ou ainda como forma de interlocução, muitas vezes, passando-se pela pessoa amada, a quem se gostaria de dirigir suas confissões, seus lamentos e desejos, outras vezes, assumindo comportamentos humanos, exercendo funções e agindo como se fosse gente.

Sobre a presença dos animais na literatura em todos os seus gêneros, podese considerar que, em boa parte das manifestações literárias, inclusive do veio popular e oral, os animais ocupam um lugar de notoriedade, constituindo-se em grandes personagens, tornando comum as suas atitudes e ações. Nesse sentido, tem-se observado que:

28 Constátase que, en efecto, na lírica popular contemporánea rexístranse numerosos motivos ou elementos (especificamente de significado erótico), tratados as máis das veces con procedementos metafóricos e/ou simbólicos pode dicirse que similares aos empregados, sete ou oito séculos antes, nas cantigas de amigo de tipo tradicional. É moi probábel que, a pesar das abismais diferenzas de todo tipo entre ambos rexistros, a orixe destes motivos e procedementos sexa a mesma: unha tradición oral antiga, pretrobadoresca. (FREIXEDO, 2012, p. 63) 
A literatura está cheia de histórias sobre animais; muitos escritores dedicaram a esses companheiros próximos ou distantes, cujos costumes eles pintaram, costumes muitas vezes profundamente assimilados aos dos seres humanos, fazendo-os participar estreitamente de nossa vida como verdadeiros protagonistas, intérpretes e caricaturas de nossos pensamentos, de nossos sentimentos, de nossas reações; animais que falam e agem como homens ou, então, que os julgam e criticam. (BRADESCO-GOUDEMAND, 1982, p. 5)

As cantigas seguintes apresentam, em seus versos, certas aves de presença habitual na fauna da região como a saracura, a arara, o louro (nome dado a uma espécie de papagaio), o canário e o pica-pau, o que vem ratificar o lugar de destaque dos pássaros, os quais se sobressaem desde o começo da história do Brasil, pois "os pássaros são um dos elementos mais característicos da fauna brasileira, a ponto de ter sido o Brasil primitivo conhecido como a Terra dos papagaios". (BRADESCO-GOUDEMAND, 1982, p. 110)

Na poesia popular nordestina, conforme versa ainda Bradesco-Goudemand (1982), o mundo animal se faz presente em tudo, sendo que essa presença traduz a riqueza de uma fauna local variada e colorida, com a qual o homem permanentemente se confronta; o imenso papel exercido pelo reino animal numa região onde parte importante da população subsiste graças à sua criação; e a coexistência familiar entre pessoas e animais no mundo rural.

Também, segundo a referida autora, esses povos sertanejos, até quando migram de um lugar para outro, estão sempre acompanhados de seus animais domésticos, como vacas e touros, cachorros e papagaios, dentre outros. Tal circunstância se assemelha à realidade das comunidades ribeirinhas, as quais, mesmo quando estão localizadas nas cidades, geralmente possuem hábitos mais ruralizados, vez que habitam regiões periféricas nas margens do rio, como se pode notar:

1

Despedida, despedida

Como deu a saracura

Bateu asa e foi embora

Coisa boa não atura. 
Eu não sou arara do rio

Eu não sou arara do ar

Arara porque não deu

Arara porque não dá

3

Que é que tu tem, meu louro

Que não quer falar

Ou eu vou pra Bahia

Ou eu torno a voltar

Meu louro foi quem disse

Quem namora quer casar

Lá em casa, tem um papagaio

Que é danado pra conversar

4

Canarinho que tá cantando

No olho da canafista

Cala boca meu canário

Quem se mata, morto fica

5

Pinica pau, que pinica no pau

Que do pau fez um tambor

Onde canta a alvorada

$\mathrm{Na}$ casa do imperador

Nas duas primeiras cantigas, a arara e a saracura podem simbolizar a liberdade, a possibilidade de fugir, de alçar voo para outras realidades, a fim de se livrar da dor, do sofrimento que acomete o eu poético. A saracura é livre para bater asa e ir embora quando não aturar mais alguma coisa. E a arara também representa a oportunidade de ir ao encontro de outras possibilidades, mas, como o eu poético afirma, não deu para ser nem arara do rio nem arara do ar, restando-lhe apenas ter de conviver com uma realidade de proibições e de desejos reprimidos. 
Frequentemente, os elementos da natureza como plantas e animais cumprem o papel de confidente, e muitas vezes, até representam o próprio ser amado, cujo nome não deve ser revelado. Em muito poucas cantigas do samba, chega-se a ver revelado o nome do ser amado, mas, em grande parte, este não tem o seu nome identificado. Isso pode ser visto nas cantigas de números três e quatro: na cantiga três, um papagaio (comumente chamado de louro e bastante encontrado nas casas ribeirinhas como animal de estimação); e na quatro, um canário. Subentende-se que há uma espécie de diálogo entre o eu lírico e esses animais que assumem o lugar de um humano, geralmente, a pessoa amada, a exemplo do que ocorre nestes versos: "Que é que tu tem, meu louro/Que não quer falar".

Como se vê, há uma preocupação com o estado do outro, com o porquê de não querer mais falar. Embora seja o louro uma espécie de papagaio, que costuma repetir palavras humanas, acredita-se que ele ocupa, nesse caso, o lugar simbólico da pessoa amada, que não pode ser revelada.

Nesse exemplo, faz-se notória uma preocupação com o louro, pois já não quer mais falar, encontra-se calado, como se estivesse pensativo, triste, passando por algum sofrimento, alguma dor causada pela distância, pela ausência do ser amado, ou por não poder estar junto do mesmo, o que era muito comum na vida dos amantes. A prisão e a vigilância que sofriam - impedindo que os amantes se encontrassem e realizassem seus desejos, chegando a sofrer de saudades - eram motivos da sua tristeza. Na canção, tal tristeza vitimava o louro.

Já no caso do canário, ave que, segundo Cascudo (2008), os indígenas tupis o consideravam como pássaro que fala ou canta bem, tal perspectiva simbólica fica ainda maior, uma vez que lhe é dado um alerta para que cale a boca, deixe de cantar, de falar, demonstrar seus sentimentos, pois "Quem se mata/Morto fica”. Um dos amantes alerta o outro para que fique calado, não revele, provavelmente, o namoro, não demonstre a sua felicidade para que não venha a despertar suspeitas e a sofrer as consequências, uma separação, um abandono ou outras punições por uma possível descoberta.

$\mathrm{Na}$ cantiga anterior (a de número cinco), encontra-se outra ave comum na região: o pica-pau, mais chamado pelos ribeirinhos pelo nome popular de "pinica-pau”. Vê-se que o eu poético, mais uma vez, faz alusão a um pássaro, deixando transparecer que este simboliza a pessoa amada que machuca o seu coração, deixando-o oco como um tambor, talvez pelo seu desprezo e desilusão ou por 
não poder viver uma relação amorosa devido a proibições, falta de liberdade, distância e outros impedimentos.

Ao afirmar que, no tambor, canta a alvorada na casa do imperador, o autor da cantiga refere-se ao amor carregado no peito como uma alvorada de sentimentos, de desejos e de sonhos. A casa do imperador representa a grandeza do sentimento, uma vez que o imperador, na época colonial, era tido como sinônimo de luxo, riqueza e poder. Muitos admiravam e desejavam a vida dos nobres, dos seus reis e rainhas na corte. Participar das festas e outras programações promovidas pela corte nos ambientes palacianos sempre representou um motivo de desejo entre o povo, especialmente, das moças, devido às possibilidades de conhecer rapazes de vida mais abastada, os considerados "bons partidos".

Todas as aves aparecem nas cantigas como detentoras de sentimentos e atitudes do próprio eu lírico ou do ser amado, o que reforça a ideia de que, na literatura, muitas vezes, os animais surgem representando o homem e a sua vivência, pois, segundo Bradesco-Goudemand (1982), quase não se encontra narrativa folclórica, de conto popular, em que os animais não estejam misturados às aventuras humanas, onde o homem não seja intérprete dessa vida paralela que acompanha todos os instantes da sua própria existência. Da mesma forma, ocorre também nos outros gêneros da literatura popular, como no caso da poética do samba de roda ribeirinho.

O tema do boi é encontrado em diversas manifestações da cultura popular e, na poesia oral ribeirinha, não poderia deixar de se fazer presente, visto que o boi é um mamífero bastante comum e criado pelos povos da região de Xique-Xique, utilizado para atender ao mercado de consumo de carne, leite, laticínios e couro, e ainda como auxiliares no transporte e na lida do campo, quando conduz o arado, a carroça e o carro-de-boi.

Assim como em quase todo o Brasil, na região ribeirinha de Xique-Xique, a criação de gado sempre tem sido vista como símbolo de prosperidade. A posse de bois, vacas, novilhos, no decorrer dos tempos, vem representando riqueza. A seguir, a próxima cantiga nos remete a tal realidade, pois retrata o gado como moeda de alto valor, já que, na região, quanto mais bois o fazendeiro venha a possuir, mais rico é considerado. Conforme se observa, os versos da cantiga revelam que uma fazenda de gado é oferecida como recompensa a quem conseguir prender o ladrão que faz a moça chorar. 
Não Chore, moça

Que o ladrão vai amarrado

Quem pegar esse ladrão

Tem uma fazenda de gado

Tem um aperto de mão

E um carinho bem carinhado

O boi, na cultura ribeirinha, vem representar riqueza, é sinônimo de vitória, de glória, de fartura, tanto no aspecto material, como também em relação às características que lhe são atribuídas como valentia, força, poder. O boi também é o herói, cujas qualidades são motivo de cobiça. Reforçando tal perspectiva analítica do boi e de sua representatividade na cultura popular, BradescoGoudermand (1982, p. 19) afirma que:

O boi é, de fato, ao mesmo tempo, o animal doméstico do qual o sertanejo tira a sua subsistência; e a fera, selvagem e livre, o monstro violento e nobre, do qual extrai a sua glória. Ele é o superbicho, o animal supremo; o bicho macho, o supermacho.

Há, na comunidade ribeirinha xiquexiquense, uma apresentação na qual se performatiza uma das variações da dança do bumba-meu-boi, de forma semelhante às que ocorrem em todo o país, e que chamamos de ciclo do boi. Conforme ressalta Ramos (2007), esse ciclo do boi pode reconhecer três origens, a europeia, ameríndia e africana, sendo que, dentre todos os autos em que o boi aparece como figura central, o mais típico e o mais geral é o bumba-meu-boi, porém não se pode filiá-lo somente à tradição natalina do boi do presépio e ao ciclo dos vaqueiros de origem cabocla. Para o referido autor,

Não nos bastam as origens ameríndia e europeia para a explicação etiológica do bumba-meu-boi. O africano trouxe uma contribuição, a meu ver fundamental [...] O bumba-meu-boi é dançado em todo o Nordeste brasileiro, sendo muitas as suas versões. (RAMOS, 2007, p. 83) 
Porém, não se pretende aqui tratar com detalhes da dança do boi apresentada pela comunidade pesquisada, mas trazer esse boi como elemento dentro de suas cantigas de samba, conforme aparece a seguir:

Quem anda na maldade à noite

É melhor do que o dia

Meu boi, Maria, é quem

Tem amor tem alegria

Na referida cantiga, o boi assume qualidades sentimentais atribuídas pelo eu lírico, quando afirma que é ele quem “Tem amor tem alegria”. O boi simboliza a pessoa amada, detentora de sentimentos considerados verdadeiros e sublimes. o boi, humanizado, passa a ter sentimentos do homem como o amor e a alegria.

Indo mais além, o boi pode ser visto como um ser alegre e que tem o amor, pois possui a liberdade de poder sair pelos campos, fugir das cercas, das amarras que lhe possam privar de ser livre. Dessa forma, o boi é trazido à cantiga, simbolizando o desejo do eu lírico de ser como ele: selvagem, astuto, podendo correr livre pelos campos. O boi representa, nessa composição, o elemento masculino, o macho, o animal supremo que goza de todos os privilégios de uma sociedade machista. O boi como personagem, como elemento de destaque em todos os gêneros da literatura popular, também navega por entre as águas da poética oral ribeirinha, nas margens do Velho Chico. Nesse sentido, Cascudo ressalta que:

Pelas regiões de pecuária, há uma literatura oral louvando o boi, suas façanhas, sua agilidade, força e decisão. Especialmente no Nordeste, onde não havia a divisão das terras com cerca de arame, os bois eram criados soltos, livres nos campos sem fim. A cada ano, os vaqueiros campeavam o gado para a apartação, separando as boiadas pelas marcas impressas a fogo. Alguns touros e bois escapavam ao cerco anual e iam criando fama de ariscos e bravios [...] Cantadores encarregavam-se de celebrar suas manhas, velocidade e poderio. Outros cantadores levavam, cantando, esses versos para outras regiões. O boi ficava célebre. (CASCUDO, 2008, p.69, grifo do autor)

Como se percebe, o boi representa a liberdade, pois vivia solto pelos campos sem fim e, quando tentavam prendê-lo, fugia. E muitos apaixonados, espe- 
cialmente as mulheres, desejavam gozar da liberdade do bicho macho. Assim, segundo Bradesco-Goudermand (1982), deve-se levar em conta que esse boi é o grande herói de uma série impressionante de folhetos, de composições literárias, nos quais aparece como adversário valoroso, livre, ativo, recusando a escravidão, desafiando os homens, muito mais como um ser selvagem, a fera de fogo, do que o animal doméstico que se recusa a ser. São comuns muitas histórias de bois dentro da cultura popular que integram esse ciclo do boi, como o Boi-Bumbá, o Bumba-Meu-Boi, o Boi-de-Reis, o Boi-de-Fita, o Boitatá, dentre outras.

O boi e o cavalo são animais muito encontrados na região e fazem parte do cotidiano dos povos das comunidades ribeirinhas, pois, juntamente com a canoa e com o barco, contribuem para a realização das atividades no campo e para as viagens, facilitando a sua vida, como se pode perceber na cantiga seguinte:

Tava dormindo

Acordei foi sonhando

Tinha uma novilha

Na roça roubando

Peguei meu cavalo

Saí na carreira

No fim da ladeira

Saí derrubando

De reconhecida importância para o povo nordestino pela sua utilidade, o cavalo aparece comumente como elemento da poesia popular do Brasil e - por que não afirmar - como um aliado em seu processo de colonização, uma vez que

O cavalo teve importância decisiva na história das civilizações e poder-se-ia mesmo afirmar que a face do mundo seria outra se o homem não tivesse encontrado esta rápida e fiel montaria [...] No Brasil, o cavalo exerce papel essencial desde os tempos coloniais, sobretudo, nas regiões pastoris do Norte e do Nordeste [...]. (BRADESCOGOUDERMAND, 1982, p. 21)

Por todo o seu importante papel na história, o cavalo passou a figurar nas festas e espetáculos populares, nos romances de vaqueiros e muito mais ainda 
na poesia popular. Como se vê na cantiga, o cavalo assume o papel de aliado do homem, do vaqueiro que sai à caça da novilha fugida, a qual se encontrava "Na roça roubando". É muito comum o gado ultrapassar as cercas, invadindo as plantações para se alimentar da produção de milho, mandioca e demais produtos. Nessa hora, o sertanejo se vale do cavalo para juntar o gado, expulsá-lo e prendê -lo novamente no devido lugar.

O cavalo, portanto, segundo Santos (2009), tem grande importância na literatura popular, inclusive em quase todas as histórias do ciclo do boi, quando aparece não como uma simples montaria, mas como companheiro do vaqueiro na luta contra o boi, conforme surge na cantiga apresentada anteriormente. Nesta, o eu lírico sai à caça da novilha, a fim de derrubá-la, prendê-la.

Além de animais, há cantigas que apresentam, em seus versos, espécies arbóreas encontradas comumente no cenário ribeirinho, a saber: a canafista e o juazeiro.

1

Canarinho que tá cantando

No olho da canafista

Cala boca meu canário

Quem se mata, morto fica

2

Lê lê juazeiro

Pra que tu bota juá

Pra cair na minha cabeça

Pra acabar de me matar

Lê lê, juazeiro, oiá, oiá

Numa região árida como a caatinga - com seus arbustos espinhosos e secos, que permanecem assim na maioria do tempo -, árvores frondosas e de copa vasta como essas duas (canafista e juazeiro) são bem valorizadas e muito úteis aos ribeirinhos, pois muitas coisas acontecem à sua sombra, desde um simples repouso fugindo do sol, até mesmo como um bom refúgio, um local para conversas, reuniões e encontros amorosos, haja vista que os arbustos e locais de muitas árvores sempre foram utilizados pelos amantes para viver, às escondidas, suas histórias, suas aventuras. 
A árvore é o ponto de encontro de animais, de pássaros como o canário e outros. É onde muitos fazem seus ninhos, alimentam-se, cantam, a fim de conquistar o parceiro para o acasalamento. Nesse sentido, a árvore vem representar, conforme Chevalier e Gheerbrant (2009), a vida em uma perpétua evolução, em ascensão para os céus. A árvore se renova em cada ciclo da natureza, despojando-se e tornando a se recobrir de folhas todos os anos.

Dentro desse âmbito simbólico, destaca-se o juazeiro, que contraria tal ciclo e, mesmo em meio à seca hostil e seu calor causticante, não se deixa morrer nem se desfaz de suas folhas, permanecendo vivo e útil. Por isso, torna-se pertinente trazer aqui a descrição do juazeiro como uma "enorme árvore copada. Característica da caatinga nordestina, esta árvore não perde as folhas nem no inverno nem durante a seca, servindo, assim, de abrigo para o gado”. (CASCUDO, 2008, p. 311)

Nas tradições populares, para os mais diversos povos, as árvores sempre estiveram numa posição de destaque, de respeito, principalmente, no que se refere aos rituais religiosos, sendo que, segundo ressalta Cascudo (2008, p. 27),

Europeus, africanos e ameríndios têm pela árvore o mesmo sentimento religioso. Todos os cultos possuem bosques sagrados, árvores dedicadas aos deuses, entes sobrenaturais vivendo dentro das árvores, ritual para as homenagens e súplicas a esses deuses.

Dessa forma, tanto os animais, nesse caso representados pela saracura, arara, louro, canário, pica-pau, o boi e o cavalo, quanto outros elementos da natureza e do cotidiano como as árvores são usados na forma de estratégias de interlocução, para a construção discursiva, baseada, muitas vezes, em metáforas e simbologias. Isso pode ser visto também na cantiga seguinte, que traz essa relação com a natureza representada por alguns elementos como: rosas brilhantes, flor e passarinhos.

Tem duas rosas brilhantes

Brilhantes são elas todas

E a senhora mais galã

Enverdece e bota flor

Onde os passarinhos cantam

Na aleluia do Senhor 
O eu lírico manifesta a sua admiração e o seu apreço para com a amada senhora, considerada como a mais galã, aquela que "Enverdece e bota flor". A cantiga inicia-se fazendo uma espécie de referência à rosa, elemento que, segundo Chevalier e Gheerbrant (2009, p. 789), "tornou-se símbolo do amor e mais ainda do dom do amor, do amor puro". A rosa, então, aparece para revelar o sentimento da alma apaixonada, do coração repleto de amor por sua senhora, que traz a beleza da rosa.

A expressão "Enverdece e bota flor" vem simbolizar o surgimento da vida, pois a flor é associada ao órgão da vida, à fecundidade, conforme versam, ainda, os respectivos autores Chevalier e Gheerbrant (2009). É apresentado, portanto, todo um ambiente primaveril, com a natureza em seu esplendor, "Onde os passarinhos cantam", cheia de vida, simbolizando esse sentimento amoroso que se encontra na alma. O ser amado é, mais uma vez, representado por um elemento do cenário natural, nesse caso, a rosa, a qual é comparada à sua senhora. $\mathrm{E}$ em meio a todo esse universo de sentimentos, a paz se consolida quando tudo acontece "Na aleluia do Senhor".

Nas cantigas de samba do grupo, notou-se a presença de peixes como a piranha, a piaba, a curimatá e o dourado, animais da fauna ribeirinha que habitam no seu universo poético, sendo que tais elementos já foram observados e analisados em outros momentos. Houve um estudo, uma análise no que concerne à sua simbologia, às comparações e funções. Sendo assim, justifica-se o fato de algumas cantigas surgirem mais de uma vez, porém com outras considerações e abordagens.

As cantigas que trazem os peixes como elementos de seus versos demonstram uma relação muito próxima com o Rio São Francisco, com a pesca e a labuta diária, especialmente, com o universo da mulher ribeirinha, conforme sugerem as cantigas a seguir:

1

No Rio São Francisco

Tem duas coisinhas belas

Cabeça de curimatá

Beijinho de moça donzela 
Dançou, dançou, piranha

Tornou dançar, piranha

Com a mão na cabeça, piranha

Com a mão na cintura, piranha

Dá um jeitinho no corpo, piranha

E uma umbigada na outra, piranha

3

Ô piaba ê, piaba ê

Valei-me Nossa senhora

Ô Piaba ê, piaba ê

Santana do Miradouro

Ô Piaba ê, piaba ê

Me bote daquele lado,

Ô Piaba ê, piaba ê

Nos braços do meu amor

Ô Piaba ê, piaba ê

4

Curimatá tá lavando

Lá na beira do rio

Ô que peixe danado

Curimatá, é dourado

Ela lava de um lado

Ele lava do outro

Ô que peixe danado

Curimatá, é dourado

Em várias circunstâncias, são atribuídas aos peixes certas características e qualidades humanas como a astúcia, a agilidade e a esperteza, dentre outras.

A presença dos peixes na poética oral ribeirinha pode também ser vista conforme apontam Chevalier e Gheerbrant (2009), como símbolo de vida e de fecundidade, em função da sua prodigiosa faculdade de reprodução e do número infinito de ovas. Nos versos da cantiga número quatro - "Ô que peixe danado/ 
Curimatá, é dourado" - o dourado é visto como "danado", o peixe que pode fecundar a sua fêmea, fazendo perpetuar a vida, pois é rápido, astuto e, quando menos se espera, desvencilha-se, some na água, considerada como sinônimo de fecundidade.

Assim, em várias culturas, como afirmam Chevalier e Gheerbrant (2009), o peixe e a água simbolizam a fertilidade. Logo, o amante representado na cantiga pelo peixe dourado assume suas características, deixando latente a relação com a conquista do amor da sua amada, da sua fêmea e a consumação do próprio ato sexual, da própria fecundação. $\mathrm{O}$ amante aparece em cantigas como essas associado a um peixe, com suas características e simbologias dentro da poesia oral. Sobre o dourado e a curimatá, já foram feitas, também, outras considerações quando se discutiram outros aspectos nessa mesma cantiga.

As cantigas em que peixes desse tipo são trazidos como elementos relevantes são retomadas outras vezes neste estudo, com o intuito de rever distintos aspectos temáticos dentro de uma perspectiva comparativa e simbólica. Acerca do dourado e da curimatá, foi feita uma abordagem em momento anterior deste capítulo. Já em relação à piranha e à piaba, posteriormente, na parte que trata da mulher na poesia ribeirinha, elas retornarão à pauta discursiva, sob uma ótica mais direcionada a esse aspecto temático.

A exuberância da flora brasileira também sempre foi motivo de exaltação dentro da literatura nacional, como é possível observar em alguns de seus romances e poesias. Na poética oral ademais aparece representada pelas frutas, muitas qualificadas como belas, exóticas, apetitosas e saborosas:

1

Menina, me dê uma lima

Da limeira do seu pai

Eu não tenho a lima não

Mas porém a lima vai

2

Menina, vamos jogar

O jogo da laranjinha

Se eu perder, você me ganha

Se eu ganhar, você é minha 
A laranja madura caiu

Caiu na água e foi ao fundo

Triste da moça donzela

Que caiu na boca do mundo

Na primeira cantiga citada anteriormente, tem-se a presença de uma fruta muito encontrada na região de Xique-Xique, a lima: "Da limeira do seu pai”. E nas duas últimas, a laranja, também uma fruta muito apreciada e presente na dieta do ribeirinho: "Menina, vamos jogar/O jogo da laranjinha" e "A laranja madura/Caiu na água e foi ao fundo”.

Do ato de pedir a lima, como se observa na primeira cantiga, vem simbolizar uma forma de o rapaz, o amante, pedir o amor, os carinhos, a entrega da moça aos seus caprichos. A lima representa o objeto do desejo, surge como símbolo do prazer, é associada à virgindade, que aparece comparada a essa lima doce, saborosa, apetitosa e cobiçada, a qual se encontra, muitas vezes, em terreno alheio, sob a vigilância de seus donos. Quando o eu lírico afirma que não possui a lima, "mas porém a lima vai”, deixa subentendida uma alusão à consumação do ato sexual.

Já na segunda cantiga, o jogo da laranjinha aparece associado ao jogo da sedução. Através dos contrastes, "Se eu perder, você me ganha/Se eu ganhar, você é minha”, torna-se evidente a estratégia da conquista, a busca da prenda, e essa prenda passa a ser representada também por uma fruta, a qual todos desejam chupá-la: a tão cobiçada laranjinha.

Conforme Cascudo (2008), na tradição popular, a laranjinha representava uma espécie de bola de cera repleta de água perfumada que se usava no jogo do Entrudo, isto é, nas festas de Carnaval, representando frutas diversas como a laranja, daí o nome de laranjinha, ou ainda lima de cheiro, ou limão de cheiro. Sendo assim, o jogo da laranjinha passa a representar um convite à festa, à diversão, à liberdade dos carnavais, momento em que se podia ganhar ou perder alguém que se deseja. Ganhar o amor, a liberdade e, também, perder a inocência, entregar-se aos prazeres carnais, o que leva à perdição, à ruptura dos dogmas sociais.

Assim como as cantigas de amigo, que, segundo Freixedo (2012), trazem, em certas composições, alguns elementos simbólicos que se referem ao erotismo, à 
sexualidade, as cantigas de samba, como se pode comprovar, também seguem esse curso simbólico, uma vez que trazem elementos e circunstâncias que sugerem tais percepções.

Na próxima cantiga, também aparece uma fruta muito comum na região: a melancia. Nesse caso, deduz-se que a mesma surge como símbolo da mulher, da conquista. Trata-se de uma fruta apetitosa, doce e de cor vermelha como os lábios da amada, pronta para ser saboreada. A melancia, a laranja madura e outras frutas representam a sensualidade e a exuberância da mulher, que, em sua juventude, encontra-se pronta para o sexo, mas é impedida pela sociedade e seus princípios.

Não fui eu, não fui eu

Que comi sua melancia

Nesta noite deve ter

Festa e muita alegria.

Nos versos anteriores, o eu poético, provavelmente um homem, diz não ter sido ele quem comeu sua melancia, afirmação da qual se subtende não ter sido ele quem tirou a virgindade da donzela. A melancia, nesse caso, passa a ser considerada como uma espécie de fruto proibido. Logo, não se sente responsável pela moça, mesmo tendo, provavelmente, praticado sexo com a mesma, visto que ela não era mais virgem e, assim, não precisa assumir os compromissos do matrimônio, prática muito comum. Por ter conseguido realizar o seus desejos e ainda eximir-se das possíveis consequências, o rapaz sugere que se faça uma comemoração, afirmando que "Nesta noite deve ter/Festa e muita alegria".

Na cantiga seguinte, outros aspectos da realidade do lugar são apresentados, como a riqueza advinda do ouro e do diamante, encontrados em abundância até o início do século passado, nos garimpos da região. Provavelmente, o sobrado também tenha sido uma construção muito comum (mas de famílias mais afortunadas) na época em que a cantiga foi criada, caracterizando assim a arquitetura local. O antigo e parcialmente conservado casario xiquexiquense ainda pode ser apreciado na contemporaneidade. Juntamente com o sobrado, a moeda "vinte mil réis” também serve para retratar uma época, certamente a colonial, como se pode observar: 
Eu sou negociante

Vendo ouro e diamante

Eu não lhe dou dinheiro

Porque não tenho trocado

Só lhe dou vinte mil réis

Na despesa do sobrado

Outros elementos relacionados ao garimpo ainda podem ser vistos nos versos trazidos pela cantiga seguinte:

\author{
Essa noite choveu ouro \\ Prata fina alumiou \\ Quero que você me diga \\ Onde meu sentido andou \\ Onde meu sentido andou pra vadiar
}

Nela, mais uma vez, aparece o ouro e ainda a prata. São elementos preciosos e raros, assim como o amor da pessoa amada. Pode-se depreender que há uma confissão à tal pessoa amada, de que algo muito bom aconteceu, talvez a própria consumação do encontro amoroso entre os amantes, o que para um deles que canta, fez chover ouro e a prata fina alumiar, simbolizando, portanto, o prazer, a satisfação, o gozo, levando à perda dos sentidos.

O ouro, nessas cantigas, vem simbolizar a conquista do amor, da entrega de um bem precioso. Como afirma Chevalier e Gheerbrant (2009, p. 669), o ouro é "considerado como o mais precioso dos metais, o ouro é o metal perfeito [...] É o filho dos desejos da natureza". Assim, também, o ouro pode ser comparado ao amor - sob o viés de um eu poético masculino -, especificamente, à mulher e à sua virgindade.

A prata, metal de exímio valor, simboliza a luz, pois, como se vê na cantiga, a "prata fina alumiou". Em se fazendo uma incursão na simbologia da cantiga anteriormente citada, vale trazer considerações sobre a prata e o ouro:

No sistema de correspondência dos metais e dos planetas, a prata está em relação com a Lua [...] princípio feminino. Tradicionalmente, por oposição ao ouro, que é princípio ativo, macho, solar, diurno, ígneo, a prata é princípio passivo, feminino lunar, aquoso, frio. Sua cor 
é o branco [...] Branca e luminosa, a prata é igualmente símbolo de pureza, de toda espécie de pureza. (CHEVALIER; GHEERBRANT, 2009, p. 739)

Dessa maneira, nota-se, nesse caso da cantiga apresentada, uma relação entre o ouro e a prata, metais nobres e cobiçados, sendo que o ouro passa a simbolizar o macho, e a prata, o eu feminino, puro e iluminado. Nessa relação estabelecida, o ouro "chove" (o macho ejacula) e a prata "alumia" (a fêmea se alegra pelo gozo).

A seguir, a próxima quadra traz outro elemento bastante comum para o povo ribeirinho nas margens do Velho Chico e que faz parte do seu dia a dia: o candeeiro (objeto destinado à iluminação durante a noite, uma espécie de candeia, da qual tem a sua origem, inclusive do nome). Segundo o Michaelis Moderno Dicionário da Língua Portuguesa (WEISZFLOG, 2009), candeia é um tipo de utensílio, luminária destinada à iluminação, cuja luz resulta da queima de azeite ou outro tipo de óleo, que alimenta o lume na torcida, pavio ou mecha que sai por um bico.

Candeeiro de dois bicos

Que alumia dois salões

Que firmeza pode ter

Quem ama dois corações

O candeeiro traz luz a muitos lugares e casas durante a noite, por exemplo, nas pescarias, nas festas dos salões e em outras atividades noturnas, além de servir para iluminar os caminhos dos encontros amorosos, pois muitos ocorrem à noite, na beira do rio, da lagoa, em ambientes ermos, a fim de que não sejam descobertos. Há a significação simbólica desse elemento trazida por Chevalier e Gheerbrant (2009), que apresenta a candeia associada ao símbolo da vida, pois, na chama ardente, móvel e colorida, há uma espécie de síntese de todos os elementos da natureza.

A chama pode ser comparada ao amor, à força de um sentimento interior e que, nesse caso, alimenta não apenas um coração, mas dois: assim como o "candeeiro de dois bicos/que alumia dois salões”, há um amor que alimenta dois co- 
rações. É uma espécie de amor dividido, em que paira a incerteza, a dúvida. O próprio eu lírico indaga: “Que firmeza pode ter/Quem ama dois corações”.

São dois sentimentos alimentados pela chama da paixão, embora se saiba que tal paixão direcionada a dois corações cause, muitas vezes, a angústia, a instabilidade e, possivelmente, dores e mágoas aos dois corações amados ao mesmo tempo. Essa chama, então, tem de ser forte nos dois bicos, para acalentar as duas paixões.

A utilização do cenário campesino, da natureza e de seus elementos permeia todo o universo da poética oral ribeirinha, assim como sempre esteve presente na poesia de tradição oral portuguesa desde quando começou a surgir no decorrer dos tempos. Nas cantigas de tradição oral, segundo Freixedo (2012), a evasão para a natureza, a ambiência natural pode ser associada a uma busca da liberdade e ao desprendimento da coerção social que, muitas vezes, tolhia o eu poético de viver de acordo com seus desejos. Essa fuga da vigilância para a natureza, cujos elementos passam a lhe servir de companhias e confidentes, pode vir a representar também o perigo de cair em tentação.

Mais um retrato dos costumes e da vida cotidiana ribeirinha é pespontado na tecedura da cantiga de roda xiquexiquense, como a que se pode apreciar a seguir:

Ô de casa ô de fora

Porta aberta vou entrando

Luz acesa clareando

Café na mesa vou tomando

O que faz, Dona da casa

Que está me reparando

No salão de eu vadiar

Na cantiga apresentada, percebe-se a vida de hábitos simples nas comunidades ribeirinhas cujas casas, em sua maioria, viviam sempre de portas e janelas abertas. Em alguns povoados e vilas de pescadores como o Mocambo dos Ventos, ${ }^{29}$ essa prática existe ainda hoje, pois é comum os seus moradores até saí-

29 O Mocambo dos Ventos é uma localidade cujos moradores são, em maioria, pescadores e descendentes de negros escravizados, o que a torna uma localidade formada por remanescentes de quilombo, embora não seja reconhecida oficialmente. 
rem para o rio ou para outras atividades agrícolas nas proximidades e deixarem as casas abertas, a panela de feijão cozinhando e o café feito na parte aquecida do fogão, chamada de trempe ou chapa.

Os povos dessas comunidades são muito solidários e exercem uma relação de parceria e de interação, pois muitos se ajudam nos afazeres, no compartilhamento de alimentos, no cuidado com as crianças e em outras atividades. Há uma intimidade entre eles que permite adentrar a casa do outro, tomar café, fazer refeições e até dormir, dentre outras ações, como se percebe nos versos: "Porta aberta vou entrando/Luz acesa clareando/Café na mesa vou tomando”.

Não somente os moradores, mas as pessoas que chegam nessas comunidades costumam ser também bem acolhidas, e recebem dos seus moradores o que eles têm de melhor. Ao realizar essa pesquisa, foi possível ao pesquisador comprovar tal hospitalidade, pelo tratamento receptivo que recebeu de todas as sambadeiras e sambadores em sua comunidade poética.

Essa cantiga de samba é comum ser cantada nas ocasiões em que o grupo percorre algumas casas na comunidade, quando se achegam à porta e pedem para entrar já cantando. Em noites de festas, os moradores costumam esperar o grupo em casa com alguma merenda - como é comum, entre eles, chamar o lanche - , geralmente composta por café, beiju, frutas da época, algumas vezes, aguardente e outras comidas que disponham no momento.

O espaço da casa, geralmente, a sala ou o terreiro em frente, eles denominam de "Salão de eu vadiar", como se pode notar nos versos das próprias cantigas. A palavra "vadiar", para eles, significa sambar, brincar, dançar e cantar. Mas, como em toda boa cantiga de samba, o jogo de sedução e o sentimento amoroso estão subentendidos, como nos versos "O que faz Dona da casa/Que está me reparando”. O samba é um momento para se investir no namoro, na paquera, é a hora de arranjar uma moça ou um rapaz para casar.

Nessa cantiga, a moça, dona da casa, lança olhares para o sambador, uma forma de demonstrar seu interesse, seu encantamento. O rapaz também aproveita para sambar bem miudinho, na pisadinha, como eles costumam dizer, dando o melhor de si para se fazer notar e seduzir.

Elementos como os descritos em todas as cantigas apresentadas aqui ajudam a compor o retrato da região, traçar a sua história, permitindo, então, que se possa, numa rede de versos, tecer o perfil, pespontar o retrato do lugar, de sua gente e de seus hábitos. Navegar pelas letras das cantigas do samba de roda 
proporciona ao leitor uma viagem no tempo e no espaço, conduzindo-o a embarcar rumo às águas que espelham um povo, suas tradições, suas identidades. Pode-se, dessa forma, fazer um passeio por suas memórias que fluem em rica correnteza cultural.

\section{O universo feminino na poesia oral do samba de roda das margens do Velho Chico}

Lemaire (1995), quando trata da mulher e suas vozes na literatura oral, sugere que as mulheres são responsáveis pela manutenção da tradição oral e acabam assumindo o papel de guardiãs de todo um tesouro precioso no âmbito da cultura de seu povo. Isso acontece nas comunidades tradicionais europeias, desde antes da Idade Média.

Ainda de acordo com Lemaire (1995), já nas comunidades tradicionais indo -europeias, a mulher sempre ocupou um papel de extrema importância nas suas comunidades, tanto no aspecto econômico quanto em relação à produção artística e poética. Isso ocorre porque, na sua lida cotidiana, vem incorporando cantos, danças, narrativas e outros gêneros da cultura oral, assumindo ainda um papel de difusora, contribuindo para a manutenção dessas práticas artístico-culturais.

Não se pode negar, como afirma Lemaire (1995), a preponderância da produção feminina, especialmente, no âmbito da literatura oral, embora essa sua produção literária tenha sido marginalizada, suprimida ou usurpada pelo homem quando se apossa de suas composições e as modifica, manipula-as, de acordo com os interesses da ideologia cristã disseminada pela Igreja Católica, já a partir da Idade Média.

Há todo um tratamento desmerecedor dado à mulher e ao seu papel dentro da sociedade, como consequência de uma ideologia patriarcalista, a qual lhe reprimia e isolava dentro de um mundo à parte, fora do mundo dos homens, sendo este, reconhecidamente superior quanto aos elementos estéticos do mundo das artes e em todos os outros papéis e funções existentes dentro de uma sociedade cujo homem era enaltecido, era quem dominava. Sobre o desmerecimento e a manipulação das tradições orais das mulheres, convém ressaltar que: 
Uma das estratégias aplicadas pela igreja para lutar contra as tradições orais das mulheres é a das confracta. Os monjes pegavam uma estrofe, ou um refrão, de uma canção bem conhecida de mulher (isto é: a melodia tradicional) e transformavam seu texto, julgado obsceno, em texto religioso e edificante. (LEMAIRE, 1995, p. 112, grifo da autora)

Era muito comum a prática da mutilação, da transformação da mensagem das canções de mulheres, muitas das quais tinham cunho erótico-sexual, em uma mensagem de acordo com a doutrina da Igreja Católica. Santos (2005, f. 39) também versa sobre esse tratamento dado à poética feminina, reforçando que:

Na Idade Média, os registros escritos eram feitos por clérigos, membros ou ex-membros da Igreja Católica que consideravam menos importante as tradições populares em geral e mais particularmente a das mulheres. Os monges adaptavam para Deus e Cristo os versos de canções populares anônimas, que tratavam de temas como o amor, a afetividade, intimidade com o amado.

Quanto às mulheres, suas danças, canções e outras manifestações recreativas, e ainda à sexualidade, essa Igreja não se apresentava favorável, mas hostilizava, segregava, tolhia. E foi dessa forma que as tradições orais, no decorrer dos tempos, foram tratadas pela Igreja Católica, a qual manifestava seu descontentamento e repreensão em seus Concílios e Capitulários.

[...] Conhece-se a amplitude das perseguições que a Igreja Católica infligiu com uma obstinação particularmente agressiva e violenta às tradições orais dos povos europeus, tanto às dos homens quanto às das mulheres. Por sua concepção 'pagã' da vida, da sexualidade, da posição da mulher, da natureza, estas tradições orais constituíam um perigo permanente de subversão, uma ameaça para as doutrinas da Igreja. [...] constata-se que as perseguições visavam sobretudo às mulheres, consideradas como instigadoras e condutoras das práticas (divertimentos, jogos, danças) às quais os homens vinham participar. (LEMAIRE, 1995 p. 110) 
Isso fez que a literatura oral viesse a sofrer perseguições, desmerecimento por toda uma dita sociedade burguesa, a qual se juntava à Igreja Católica e toda a sua secular perseguição. Com isso, as práticas culturais oriundas dessas tradições de mulheres acabaram sendo passadas à clandestinidade.

Por um período considerável, muitas mulheres, as consideradas guardiãs das tradições populares, procuravam esconder, recusavam-se a falar, a demonstrar a sua poética, as suas canções, por vergonha e medo de serem excluídas, perseguidas pelos guardiães da moral e dos bons costumes doutrinários.

Segundo Vasconcellos (1904), a Igreja Católica não se posicionava favoravelmente às práticas culturais populares, as quais consideravam pagãs e subversivas aos princípios cristãos, representando um perigo à doutrina de coerção e controle social pregada por tal instituição. A Igreja Católica considerava todos os cânticos não sacros, todos os bailes, todos os jogos e momos como atos de torpeza, pois eram indecorosos, luxuriosos e irreverentes. Essas atividades eram vistas como sacrilégios e meras obscenidades, coisas diabólicas.

E por tais práticas serem ligadas e mantidas pelas mulheres - que as organizavam e reproduziam em seu meio social, com seus cantos, danças e festejos -, elas eram discriminadas, sendo relegadas a um patamar de inferioridade social. Contudo, mesmo às margens, essas práticas conseguiram sobreviver, chegando aos dias de hoje.

Por esse motivo, tais tradições permaneciam somente no seio das famílias, entre os grupos formados por pessoas mais íntimas. Essa realidade, muitas vezes, ainda é notada em meio às comunidades poéticas como a das margens do Velho Chico, quando muitas das sambadeiras e narradoras de histórias em alguns momentos chegam a se sentir envergonhadas por apresentarem suas cantigas, seus sambas e suas narrativas.

Todavia, nos últimos anos, desde o início do trabalho que vem sendo desenvolvido de fortalecimento e divulgação da cultura popular no município de Xique-Xique, especialmente através de pesquisas - como esta - e de outras ações de extensão comunitária da UNEB, esse quadro de intimidação e vergonha já não mais retrata o grupo "É na pisada ê", que se afirma e demonstra ter orgulho e motivação para realizar seus festejos e apresentar a sua roda de samba.

É preciso, no entanto, considerar que ainda existe um posicionamento depreciativo e preconceituoso contra as práticas culturais populares femininas, embora com menos rigor. Em muitas comunidades, no que se refere a alguns 
aspectos doutrinários da Igreja quanto às mulheres (pois ainda lhes são atribuídas determinadas normas de conduta), elas ainda sofrem certos preconceitos e marginalizações em relação ao seu papel social e familiar, às suas práticas laborais e artísticas.

Isso ocorre como consequência de uma estratégia doutrinária da Igreja com o objetivo de apagamento das tradições orais, tidas como pagãs, por considerar que elas vão de encontro aos princípios cristãos defendidos por “[...] clérigos, membros ou ex-membros da Igreja Católica que detestavam as tradições populares em geral e mais particularmente a das mulheres”. (LEMAIRE, 1995, p. 111)

Os clérigos, membros e pessoas ligadas à Igreja Católica, eram os responsáveis pelo registro da literatura medieval em línguas vernáculas, e como não eram simpatizantes das tradições populares, em especial, das femininas, pode-se afirmar que tal antipatia foi um fator determinante da exclusão dessas tradições dos compêndios de literatura medieval, contribuindo para a sua marginalização.

Um dos maiores motivos para tal ocorrência, de acordo com Vasconcellos (1904), foi o combate pela Igreja Católica das crenças idolátricas e rituais gentílicos, costumes pagãos, conservados com inconsciência, sobretudo, entre a gente do campo, embora chegasse também a ocorrer em classes mais abastadas.

Esse posicionamento da Igreja, ainda hoje, é notado, pois, conforme relatam os próprios integrantes do grupo, de início, sofreram discriminação pela paróquia local em Xique-Xique e não podiam levar o seu samba às festas e rituais católicos. Só se faziam presentes com suas danças, ritmos e cantigas do lado de fora da igreja, em momento à parte, sem muita ênfase, sob o enfrentamento dos desaprovadores olhares dos líderes religiosos.

Porém, diante da notoriedade e das atividades de inclusão de grupos marginalizados por parte de outros segmentos da sociedade - por meio de secretaria, órgãos e instituições públicas responsáveis pelas (ou comprometidas com) áreas de Educação e Cultura - está havendo uma democratização também do espaço religioso, e o grupo tem sido, ultimamente, acolhido pela própria Igreja, visto que uma das integrantes e coordenadora do grupo de samba também é uma das líderes religiosas na paróquia, participante ativa de movimentos de evangelização e de acolhimento religioso.

A referida integrante exerce uma liderança notória dentro da Igreja Católica, promovendo atividades relacionadas a grupos de jovens, a grupos de música etc. Com um perfil acolhedor e democrático, vem conseguindo abrir as portas da 
Igreja para membros das comunidades ribeirinhas, cujas práticas religiosas nem sempre são aceitas. Como se sabe, há um movimento de rejeição ainda muito grande dentro das igrejas, incluindo as evangélicas, no que concerne ao samba e às práticas religiosas de ascendência e herança cultural africanas, consideradas por muitos como demoníacas, pagãs.

Por ser mulher, ter fenótipo negro predominante, fazer parte de uma cultura cujas marcas também se pautam na afrodescendência, a referida integrante afirma saber o que é sentir na pele o tratamento destinado às práticas culturais que se afastam do padrão estabelecido por uma representação de um segmento social elitista, racista e patriarcal. Tal postura autoafirmativa, politizada e atenta às agruras da sociedade, possivelmente, tenha sido a mola mestra para que essa integrante do grupo "É na pisada ê" defendesse (e continue defendendo) o direito de o samba de roda ribeirinho ser manifestado com maior liberdade em Xique-Xique. A sua formação na Academia e sua vinculação à Igreja talvez tenham facilitado as suas ações em defesa da cultura do seu povo.

A ressignificação de olhares pode ser considerada como uma estratégia da Igreja para conquistar mais fiéis, uma ideologia que se pauta na inclusão e no acolhimento, embora se note que isso aconteça ainda com certas restrições a determinadas práticas. Tal posicionamento da Igreja Católica, desde o início da expansão do cristianismo na Idade Média, já era adotado, pois, conforme Vasconcellos (1904), a Igreja não abriu mão totalmente das práticas pagãs, mas as utilizou como aliadas no processo de cristianização, ressignificando, modificando cantos e jogos profanos, danças e representações cênicas e adotando a utilização da paródia como um dos maiores instrumentos nesse processo de cristianização. Inclusive, ainda segundo a referida autora, foi procurando substituir aos poucos a linguagem rebuscada, com sua fraseologia e sintaxe clássicas e os metros exageradamente difíceis pelo estilo mais simples e de versificação acentuada e rimada da abominada, profana e condenada poesia em latim falado pela plebe, o chamado vulgar. Diante dessas considerações, pode-se afirmar que a Igreja:

Igualmente aproveitou as melodias predilectas, então correntes entre os povos, para mais facilmente fazer cursar os textos novos ao divino [...] Assim, o elemento profano, vulgar, pagão, ligado a festas religiosas, tinha assegurada a sua existência. (VASCONCELLOS, 1904, p. 841) 
É dentro desse âmbito visionário que se observa a propensão democrática, a qual se aplica na Igreja atualmente, em especial, a católica, na paróquia da qual fazem parte as sambadeiras e sambadores do grupo. Isso acontece porque, como sempre tem ocorrido, é preciso, também, nos dias de hoje, utilizar estratégias semelhantes para não perder fiéis e, enfim, trazer as pessoas para o seio da fé cristã.

Como resultado da política de acolhimento, o grupo de samba agora já pode apresentar-se nas festas da paróquia e em determinados rituais católicos. Até alguns cantos e ritmos utilizados nas celebrações vêm adotando certas características mais próximas do samba, como a utilização de tambores, caixas e outros instrumentos, a inovação nos ritmos e apresentações, onde se podem notar mais alegria e maior descontração nesses momentos.

Como uma prática do passado medieval, em que, segundo Vasconcellos (1904), eram comuns, nas proximidades da Igreja, depois das cerimônias religiosas, rituais de comemoração, festas e danças, ainda hoje, acontecem rodas de samba na comunidade ribeirinha. Nessas ocasiões, espraiam-se as suas danças e representações ligadas a um santo padroeiro ou causa religiosa, casamentos, quermesses e outras atividades. Tais circunstâncias e práticas ideológicas disseminadas por uma elite social de valores etnocêntricos (cristãos e patriarcais), contribuem, até hoje, para que as manifestações da cultura popular, em especial, a poética oral, sofram certo apagamento diante do cânone elitista, branco e cristão.

Há também outras considerações plausíveis no que concerne ao posicionamento marginal das tradições orais femininas, como o monopólio dos homens na vida econômica, os quais acabaram relegando as mulheres à vida privada. Essas tradições acabam ratificando um processo de coerção, de uso de estratégias de silenciamento das vozes femininas, pois as tradições orais, não só as que representavam as vozes das mulheres, mas até as dos homens, certamente poderiam causar problemas à ideologia burguesa e cristã, a qual as julgava como uma ameaça ao controle social, podendo chegar a prejudicar a sua supremacia.

Mesmo assim, o que se vê, portanto, é a sobrevivência das tradições orais e populares inclusive em meio a um universo desfavorável. As vozes dos homens e, principalmente, das mulheres não se calaram, continuam a cantar. E a mulher permaneceu ocupando um lugar de destaque em meio a essas práticas populares, mesmo sofrendo perseguições e apagamentos. 
Para concluir essa abordagem discursiva acerca das práticas tradicionais de cunho oral no decorrer da sua história, faz-se oportuno, então, trazer os seguintes questionamentos de Lemaire (1995, p. 123), para os quais, diante de toda a argumentação até aqui apresentada, tem-se uma visão conclusiva formada.

\begin{abstract}
Será que o desprezo e as perseguições das quais estas foram vítimas não se aplicariam, em parte, pelo fato de que elas davam um lugar preponderante à voz das mulheres, fenômeno impossível de admitir no interior do discurso oficial? A essas vozes de mulheres que propagavam, além do mais, as verdades, o vivido, as tradições, as crenças que não eram da civilização cristã e burguesa, e que, por esse motivo mesmo, tentaram, em vão, arrancar até a raiz?
\end{abstract}

Ora, um povo se fortalece em suas práticas culturais, na manutenção de suas tradições e dar vez e voz, dar lugar a essas tradições orais e populares, significaria o risco da perda do poder, do controle econômico e social pela elite burguesa, patriarcal e cristã, a qual se pautava em princípios muitas vezes contrários aos que eram disseminados pelas práticas tradicionais orais.

Mesmo diante de um cenário historicamente desfavorável, as mulheres que fazem parte do grupo de samba "É na pisada ê" conseguiram manter suas tradições e se destacar com a sua poesia oral. No entanto, pode-se afirmar que, em aspectos relacionados ao seu papel e à sua função social, ao seu trabalho e comportamento, essas mulheres ribeirinhas ainda ocupam um lugar ratificado pelas marcas da subalternidade.

Isto se deve às próprias práticas e à organização da sociedade burguesa capitalista. Primeiro, através da divisão sexual do trabalho, delimitando o espaço em que o homem e a mulher deveriam atuar; segundo, através das instituições que sustentavam e alimentavam a sociedade e que modelavam os seus papeis. (ALVES, 2005, p. 124)

Nas quadras a seguir, está clara essa delimitação dos papéis femininos e o controle de suas ações, na maioria dos casos, pelo próprio marido, o pai ou o irmão, como se pode observar: 
Ô pega a cadeira

E assenta mulher

A mulher que não assenta

Que diabo quer em pé?

2

Ô barre a casa mulher

Eu mandei

Ô barre a casa mulher

Eu não sei não

A presença de um eu lírico que ordena a mulher a se sentar, a ficar quieta, representa essa autoridade conferida ao homem para com o sexo feminino. Há aqui uma ideologia de superioridade do homem em relação à mulher, a qual, neste discurso, deve prestar-lhe obediência. Intrinsecamente, a ideologia reproduzida no discurso é a de que a mulher ideal deveria submeter-se ao companheiro e fazer o possível para vê-lo satisfeito.

Reproduz-se, então, a identidade de uma mulher como serva do marido, uma visão bem próxima dos preceitos cristãos registrados de maneira prescritiva, em seu livro sagrado, a Bíblia. Nessa visão patriarcal estabelecida, a mulher deve ter um comportamento exemplar, estando sempre quieta, com gestos e risos comedidos, sem muito se fazer notar, sem chamar a atenção. É como se estivesse sendo vigiada sempre, o que, muitas vezes, resulta na fuga desse espaço de tolhimentos, a fim de buscar a liberdade dos ambientes da natureza como o rio, os campos, as florestas.

Ainda na mesma cantiga, provavelmente, uma voz masculina lhe ordena que varra a casa, que cumpra com os seus afazeres domésticos. Ela aparece, então, como subalterna, sendo comandada, tendo de cumprir as determinações. "Varrer a casa" assume o lugar de várias outras atividades domésticas que ela tem de realizar, já que, em sua lida diária, as atividades não são poucas.

Como forma de demonstrar sua insatisfação, a mulher afirma não saber varrer, o que pode até não ser verdade, mas é uma forma de se negar às ordens, de se mostrar, também, que não tem a obrigação de saber fazer todas as atividades laborais destinadas à mulher. Isso demonstra ir de encontro ao estereótipo da 
mulher prendada, que deve saber executar, com esmero, todas as atividades que lhe competem. Em momentos como esse, a poesia dá uma certa voz à mulher, talvez, nesse caso, devido ao fato de a liderança do grupo ser feminina. Trata-se de um samba de mulheres, em maioria.

Contudo, em linhas gerais, essa mulher acaba sendo silenciada quando ousa querer sobressair-se, rebelar-se. Isso se comprova nos versos "A mulher que não assenta/Que diabo quer em pé”. A palavra imperativa "assentar”, além do sentido literal de sentar, assume a conotação de silenciar, coibir uma série de situações por que passa a mulher em seu cotidiano, tais como: as vontades e os desejos reprimidos; a negação da liberdade no espaço público; a imposição dos afazeres domésticos; dentre outras.

Paixão (1991), bem como outros autores que discutem a temática do papel social da mulher, destacam o silenciamento da voz feminina no decorrer da história. Segundo a autora, a voz que sempre sobressaía era a do homem, aquele que sempre falou sobre a mulher, que imprimia, em seu discurso, uma ideologia machista. O homem, durante muito tempo, ocupou o lugar de sujeito do discurso, falando pela mulher, o que o levou a ocupar o lugar de dominação sobre sua voz.

Embora se saiba que, nos últimos tempos, tem havido uma desconstrução desse paradigma e que as mulheres, cada vez mais, tornam-se donas de suas vozes, ainda se tem consciência de que essa ideologia de subalternidade feminina permanece enraizada em muitas culturas, emergindo, em vários casos, em manifestações poético-literárias. É o que ocorre na comunidade poética do grupo "É na pisada ê", como se comprova em muitas das suas cantigas de samba.

Até hoje, isso vem ocorrendo em nossa sociedade, devido a um processo de colonização mental implantado pelo eurocentrismo patriarcal e cristão há séculos. Muitas vezes, as próprias sambadeiras acabam reproduzindo em suas cantigas e performances esse discurso opressor de inferiorização feminina, cuja mulher aparece estigmatizada por uma ideologia machista.

Nesse âmbito temático, a cantiga que segue demonstra uma mulher em meio aos seus afazeres, os quais parecem ser tantos que a deixam enlouquecida, perdida, sem rumo do que fazer, agindo como uma louca, conforme os próprios versos descrevem. Como se vê nos versos, a mulher executa muitas tarefas cotidianas, o que a perturba e a torna insana. 
Nota-se uma espécie de grito de socorro, pois retrata a angústia de tantas tarefas a cumprir, praticamente sem a ajuda de ninguém, muito menos do marido, que se restringe ao trabalho na lavoura, na pesca, no comércio etc., e nunca executando tarefas domésticas, atribuídas, até os nossos dias, na maioria dos lares, às mulheres, chamadas de donas de casa.

Essa mulher tá doida, tá doida tá

Essa mulher tá doida, tá doida tá

A mulher lava a roupa, doida

A mulher pega a água, doida

A mulher pega a lenha, doida

A mulher lava os trem, doida

A mulher varre a casa, doida...

Essa mulher tá doida, tá doida tá

Essa mulher tá doida, tá doida tá

São listadas, na cantiga, várias atribuições femininas como: lavar roupa, a louça, buscar água no rio, varrer a casa, pegar lenha no campo para cozinhar. Enquanto cantam, as sambadeiras vão inserindo, à medida em que se lembram, outros afazeres destinados às mulheres. Dessa forma, representam seu estado de sofrimento, de exploração, o que a conduz à loucura, uma vez que são tantas coisas, que ela não dá conta e enlouquece.

É um momento cômico na performance, porque, ao sambar, como já foi dito antes, a mulher age como se estivesse louca, descontrolada, rodopiando, sambando freneticamente. Entretanto, pode ser considerado também como um momento de protesto, de chamar a atenção para a sua excessiva jornada doméstica, a qual ela tem de exercer sem a ajuda do marido, que, quando chega, como é possível observar numa realidade tão comum ainda em nossa sociedade, exige receber a atenção, os cuidados da mulher. A voz feminina, em mais esse caso, faz-se presente, trazendo à superfície gritos de insatisfação e de protesto pela situação em que vive, mesmo que de uma forma discreta, muitas vezes, amparada em metáforas.

Essa mulher assoberbada, além de "lavar a roupa, doida e de varrer a casa, doida”, dentre tantas outras atribuições, precisa, nesse momento, deixar tudo o que tem para fazer, para auxiliar no banho, na alimentação e demais cuidados 
para com o marido e até os filhos, irmãos, sobrinhos. Em casos como esse, notase a manifestação da ideologia machista que determina os papéis exercidos pelo homem e pela mulher, sendo que a mulher deveria cuidar da casa e de todos os afazeres relacionados à vida doméstica, cuidar dos filhos e do marido. Já o homem deveria propiciar o sustento da família, o qual vinha, no contexto apresentado, geralmente, das atividades do campo, da pesca e do comércio.

Mas as mulheres do grupo "É na pisada ê" têm se destacado em meio a esse cenário desfavorável e chegam também a ocupar papéis relevantes dentro da comunidade. Sabe-se que muito da ideologia patriarcal ainda está intrínseca nas práticas desses povos ribeirinhos, contudo, nota-se que, no caso desse grupo, as mulheres exercem a liderança, tendo as senhoras Anita e Giselda à frente das suas atividades, nas quais as sambadeiras possuem lugar de destaque. As cantigas, os passos, as coreografias e demais aspectos estão sob a responsabilidade dessas mulheres.

Há o respeito dos integrantes masculinos do grupo: os sambadores e tocadores de instrumentos, os quais acatam um processo hierárquico, submetendo-se às regras estabelecidas pela liderança, de modo harmônico, sem conflitos nem imposições.

Na cantiga da piranha, a seguir, apresentada novamente, depreende-se que a mulher é comparada à piranha em sua dança, em sua maneira de se comportar. Ao ser relacionada a essa espécie de peixe, a mulher passa a assumir suas qualidades, sendo considerada como perigosa, aquela que desvirtua o homem, que o seduz, conforme se pode notar nos versos:

Dançou, dançou, piranha

Tornou dançar, piranha

Com a mão na cabeça, piranha

Com a mão na cintura, piranha

Dá um jeitinho no corpo, piranha

E uma umbigada na outra, piranha

Na roda, durante a cantiga, a mulher dança "Com a mão na cabeça/Com a mão na cintura”, sensualizando, como se estivesse insinuando-se em uma espécie de jogo de sedução. A piranha sempre foi considerada como um animal voraz, astuto, sagaz que envolve e devora a sua presa. 
Enfim, a presença da piranha, que, segundo Cascudo (2008), é um animal tão temido no cotidiano dos pescadores, dos indígenas e do povo em geral, surge como um alerta para o comportamento social da mulher, a qual, em grande parte da história, é vista ocupando um lugar inferior quanto aos seus direitos e comportamentos dentro de uma sociedade, que sempre procurou, através de meios coercitivos, fortalecer uma concepção de mulher submissa, fiel, pura, quieta, dedicada aos afazeres domésticos e à maternidade.

Dentro de um panorama histórico, vê-se que essa ideologia vem se fortalecer ainda mais na Idade Média com a difusão do cristianismo, contribuindo, até os nossos dias, para a sua consolidação. Em épocas diferentes, essa visão estereotipada da mulher não se afastava do ideal traçado pelo poder patriarcal. E foi assim também no século XVIII, mesmo com a filosofia iluminista e seus ideais centrados na liberdade, igualdade e fraternidade da Revolução Francesa, em que "a maior parte dos homens das Luzes ressaltou o ideal tradicional de mulher silenciosa, modesta, casta, subserviente e condenou as mulheres independentes e poderosas”. (PINSKY; PEDRO, 2003, p. 267)

Esse lugar ocupado pela mulher na sociedade também não muito se diferenciou durante o século XIX, pois, mesmo com a ampliação de algumas possibilidades, do florescimento do feminismo e da ação das mulheres em diversos movimentos sociais, essa visão centrada na desigualdade e submissão ainda continuou impregnada e difundida, conforme apontam Pinsky e Pedro (2003, p. 265-266):

\footnotetext{
É verdade que esse século popularizou o ideal da mulher restrita à esfera doméstica, limitada ao cuidado do lar e da família, maximizou o imaginário da segregação sexual dos espaços público e privado, reforçou concepções tradicionais da inferioridade feminina, negou às mulheres muitos direitos e impôs muitos obstáculos à sua independência.
}

Desse modo, cada vez mais, foi se estabelecendo esse ideal de mulher, o qual era referendado nas escolas, já que estabeleciam uma educação diferenciada para homens e mulheres, vindo a reforçar ainda mais a desigualdade entre os papéis atribuídos a cada sexo.

A partir do final do século passado, mesmo tendo sido iniciada a ampliação das possibilidades de atuação das mulheres, novas oportunidades de emprego, 
bem como outras conquistas sociais, ainda hoje, no século XXI, a igualdade pretendida não se aplica, pois:

Os estereótipos de gênero atravessaram os tempos e naturalizaram a diferença entre o masculino e o feminino, como se essa visão social e cultural que varia a depender da civilização, época e povo, fosse uma característica biológica. Até hoje, é predominante entre as instituições sociais, tais como a família e a escola, as idéias preconcebidas do que seria apropriado para os indivíduos a depender do sexo. E mais do que isso, essa hierarquia entre os gêneros, na qual o ser masculino é visto como superior ao feminino, mantém-se na atualidade até no mercado de trabalho. Embora desempenhe as mesmas funções que os homens, as mulheres ainda ganham menos que eles, como provam algumas pesquisas. (PALMEIRA; SOUZA, 2008)

Nesse sentido, nota-se que esse modelo de comportamento e de tratamento dispensado às mulheres continua, muitas vezes, sendo reproduzido por imposição das estruturas políticas, econômicas e sociais, inclusive por muitas dessas mulheres. O modelo de papel social tipicamente feminino ainda se consolida nos últimos tempos, pois, segundo Lemaire (1995), cada vez em que seu condicionamento político e histórico torna-se mais aparente, tende a deslizar imperceptivelmente em direção a um "eterno feminino", justificador de novas restrições e normas, impostas às mulheres.

Mas as mulheres ribeirinhas vêm fazendo valer suas vozes quando sambam e cantam os seus versos, para se tornarem mais fortes e manterem vivas as suas tradições. Pode-se depreender que a voz feminina encontra-se mais firme na maioria das composições cantadas pelo grupo, devido ao fato de o grupo ser liderado por uma mulher e de as mulheres serem maioria e se destacarem. Sendo assim, mesmo dentro de um universo machista, o fato de o grupo ser liderado por uma mulher dá às sambadeiras uma possibilidade de cantar a sua voz, a sua realidade, a sua vida, e, em muitos momentos, vociferar os seus desejos, os seus ideais.

A liderança exercida por dona Anita contribui para a permanência dessa voz em meio a uma confluência de contrariedades, que, de certa forma, acabam mais abrandadas pela força que essas mulheres vêm demonstrando, ocupando o 
seu lugar dentro da comunidade poética. Por ser um samba de roda comandado por mulheres, torna-se mais fácil que estas sejam ouvidas, vistas e entendidas. Mesmo com discursos possivelmente desfavoráveis, são capazes de romper as barreiras do preconceito para que possam emergir de águas incertas rumo ao reconhecimento, à manutenção de suas tradições, aqui representadas pela poesia oral do samba de roda.

A dança da piranha trazida pelas sambadeiras da região de Xique-Xique é apenas uma das variantes que ocorre no Brasil, em especial, no Brasil Central. Tal constatação vem ratificar a ideia da riqueza e da diversidade da cultura ribeirinha, a qual se constrói, como se pode comprovar, a partir do diálogo com diversas outras práticas.

Segundo Cascudo (2008), a dança da piranha é uma dança popular no Brasil Central. Infere-se, portanto, que a mesma pode ter chegado à região de XiqueXique, através do próprio Rio São Francisco e de seus navegantes, pois o rio, na época, era considerado a porta de acesso para as interações em todos os seus âmbitos, já que tudo chegava e saía através do rio. Para comprovar essa relação entre essas duas danças e cantigas, apresenta-se, também, a versão de Antônio Americano do Brasil (1973) em seu Cancioneiro de trovas do Brasil Central:

Chora, chora, piranha,

Torna a chorar, piranha

Põe a mão na cabeça,

Piranha!

Põe a mão na cintura...

Dê um sapateadinho...

Mais um requebradinho,

Piranha!

Dize adeus ao povo, piranha.

Pega na mão de todos, piranha!

Segundo Antônio Americano do Brasil (1973), essa é uma dança do Brasil Central, da qual participam homens, mulheres e até crianças que formam uma grande roda, saindo do meio dela um dos dançadores, executando passos diversos ao mesmo tempo em que os demais participantes da roda cantam e dançam, girando à esquerda e à direita. A tal piranha na roda faz o que lhe mandam, cho- 
rando e pondo a mão na cabeça. Por fim, conseguindo agarrar a mão de qualquer participante da roda, puxa-o para ocupar o seu lugar no meio do círculo, invertendo-se os papéis.

Como se pode observar, a dança da piranha é realizada pelo grupo "É na pisada ê", de forma semelhante, havendo, portanto, algumas variações. Em vez do choro, a piranha dança, levando também as mãos à cabeça e à cintura. Faz um jeitinho no corpo, o que deve ser semelhante ao requebradinho e ao sapateadinho, finalizando com uma umbigada, em vez de pegar na mão. Entende-se, como já foi abordado, que a umbigada assume o lugar de pegar na mão, por ser uma marca do samba de roda, das práticas culturais afrodescendentes, pois a região é formada por muitos negros, cuja maioria é descendente de quilombolas.

Esse exemplo, por conseguinte, é apenas uma comprovação da interação entre as diversas manifestações que formam a cultura popular brasileira. Como a dança da piranha, outras podem também ser encontradas em forma de variantes, por todo o território brasileiro e ainda em outros continentes como o europeu e o africano.

Uma outra cantiga traz, em seu refrão, a piaba, também um tipo de peixe muito comum na região. Ela nos conduz à percepção de que "as comparações com o mundo animal constituem procedimento constante de estilo, que mostra até que ponto a fauna está inserida no mundo dos homens” (BRADESCOGOUDEMAND, 1982, p. 83), como se nota nos versos a seguir:

Ô piaba ê, piaba ê

Valei-me Nossa senhora

Ô Piaba ê, piaba ê

Santana do Miradouro

Ô Piaba ê, piaba ê

Me bote daquele lado,

Ô Piaba ê, piaba ê

Nos braços do meu amor

Ô Piaba ê, piaba ê

Nessa cantiga, a expressão "Piaba ê, piaba ê" é repetida entre os versos. Por ser uma espécie de peixe, pode-se perceber a piaba, conforme versa Chevalier e Gheerbrant (2009), como símbolo de fecundidade, de vida e de sabedoria. A 
piaba pode ainda ser vista como uma espécie de inspiração ao eu poético, provavelmente feminino e preso às redes da subalternidade e do controle social, para que possa estar do outro lado do rio nos braços do amado, realizando seus desejos mais íntimos.

A piaba, ligeira, livre e esperta, que vive nadando por entre as águas, vem representar a liberdade de ir e vir, de poder estar onde e com quem quiser, "nos braços do meu amor”, sem ter de sofrer sanções da sociedade da qual faz parte. Como a piaba, a mulher deseja viver livre e feliz. Para isso, apela à Nossa Senhora, pedindo-lhe sua intervenção, outro aspecto bastante encontrado nos versos da poesia ribeirinha.

Em se tratando ainda da relação entre a mulher e a poesia oral, pode-se acrescentar, como exemplo dessa semelhança temática entre a poética oral ribeirinha e a literatura medieval portuguesa, o fato de que os aspectos do universo feminino, da lida diária e do sentimentalismo amoroso da mulher acabam assemelhando-se ao universo das cantigas líricas medievais em Portugal, especificamente, as de amigo, estabelecendo-se uma espécie de relação entre essas duas formas de poesia.

Uma das características para que uma cantiga lírica medieval possa ser considerada como de amigo, conforme Lemaire (1987, p. 44, tradução nossa), é a autoria feminina, a representação de um discurso da mulher, com suas lamentações, queixas e relatos do cotidiano, uma vez que "o sujeito que canta nas cantigas, é uma mulher [...] um discurso atribuído a uma mulher”. ${ }^{30}$

Também coadunam com tal assertiva estudiosos da literatura portuguesa, como Saraiva e Lopes (2001) e Moisés (2007), o qual ainda acrescenta que essas mulheres (correspondentes ao eu lírico das cantigas medievais), em linhas gerais, eram pertencentes às camadas populares da sociedade, circunstância que se equivale à da poesia oral ribeirinha, cujas sambadeiras são, em maioria, pescadoras, tecedeiras de rede e donas de casa. Assim, essas duas modalidades poéticas, acabam se aproximando em mais esse aspecto.

É nessa perspectiva analítica que se busca fazer aqui essa comparação entre tais manifestações da lírica popular, isto é, pelo campo temático e por representar o universo feminino, com seus desejos e sentimentos, os quais nem sempre

30 "le sujet qui chante dans les cantigas, est une femme [...] un discours attribué a la femme". (LEMAIRE, 1987, p. 44) 
se revelam, pois, como aponta Lemaire (1987, p. 83, tradução nossa), nas cantigas de amigo, "as jovens moças que falam do seu amor para um amigo, não dizem jamais o seu nome, nem o do seu amante ou dos seus amigos". ${ }^{31}$

Ainda para a referida autora, essas cantigas se dão, em sua maioria, numa espécie de monólogo, endereçado a si mesma, à sua mãe, a outros amigos, ao próprio amado, a um santo, a Deus, ao mar etc. Mas também pode acontecer sob a forma de diálogo. Dessa maneira, também ocorre nas cantigas do samba de roda das margens do Velho Chico, como se observa, por exemplo, na cantiga a seguir, em que a mulher endereça a um santo, a sua lamentação pelo abandono e desprezo do marido:

\section{Oh Santo Mariano \\ Me dê outro marido \\ O marido que vós me deu \\ Não quer falar comigo}

Conforme Freixedo (2012), as cantigas de amigo traziam essa representação do universo feminino, o sentimento amoroso da moça, sua relação com a natureza, dentre outros aspectos. Porém, é preciso, segundo Lemaire (1987), atentar para as interpretações generalizadas e, muitas vezes, absurdas que alguns estudiosos têm feito dessas cantigas, o que conduz a interpretações errôneas não condizentes com a verdadeira situação e realidade.

Assim, a poética oral ribeirinha também se manifesta e tem a mulher e sua realidade como um dos seus maiores fios temáticos. Já no aspecto estrutural, as características de ambas se diferenciam em alguns aspectos, a exemplo da composição das estrofes, dos versos e outros. Por isso, limita-se a abordar essa relação de semelhança entre essas modalidades de poesia, apenas a partir de um eixo temático que traz a representação da mulher, do seu mundo, dos seus sentimentos.

Como já foi destacado, no grupo de samba "É na pisada ê", a maioria dos integrantes é formada de mulheres de classe social menos abastada. Inclusive a líder do grupo, dona Anita, é que guarda a sua história, os elementos dessa tradição, desde que herdou a liderança de seu avô. Ela é uma espécie de memó-

31 "les jeunes filles qui y parlent de leur amour pour leur ami ne donnent jamais leur nom, ni celui de leur amant ou de leurs amies". (LEMAIRE, 1987, p. 83) 
ria viva, guardadora do samba com suas danças e composições poético-literárias, também compositora de outras cantigas que vieram sendo incorporadas ao repertório.

Essas composições literárias de autoria feminina no samba ribeirinho demonstram, portanto, que, independente do tempo de criação, a poesia traz em si um retrato de uma cultura, de um contexto social, de um lugar. Assim sendo, tanto a poética oral medieval ibérica quanto a das margens do Velho Chico, inclusive a dos dias atuais, trazem as marcas de seus compositores com seus ideais e sentimentos. Nesse caso, pintam um retrato íntimo de um eu poético, em maioria, feminino. 